\title{
De rol van arbeidsmarktinformatie in de opleidingskeuze van mbo'ers
}

Citation for published version (APA):

Fouarge, D., Künn, A., \& Punt, D. (2017). De rol van arbeidsmarktinformatie in de opleidingskeuze van mbo'ers. ROA. ROA Reports No. 009 https://doi.org/10.26481/umarep.2017009

Document status and date:

Published: 01/01/2017

DOI:

10.26481/umarep.2017009

Document Version:

Publisher's PDF, also known as Version of record

\section{Please check the document version of this publication:}

- A submitted manuscript is the version of the article upon submission and before peer-review. There can be important differences between the submitted version and the official published version of record.

People interested in the research are advised to contact the author for the final version of the publication, or visit the DOI to the publisher's website.

- The final author version and the galley proof are versions of the publication after peer review.

- The final published version features the final layout of the paper including the volume, issue and page numbers.

Link to publication

\footnotetext{
General rights rights.

- You may freely distribute the URL identifying the publication in the public portal. please follow below link for the End User Agreement:

www.umlib.nl/taverne-license

Take down policy

If you believe that this document breaches copyright please contact us at:

repository@maastrichtuniversity.nl

providing details and we will investigate your claim.
}

Copyright and moral rights for the publications made accessible in the public portal are retained by the authors and/or other copyright owners and it is a condition of accessing publications that users recognise and abide by the legal requirements associated with these

- Users may download and print one copy of any publication from the public portal for the purpose of private study or research.

- You may not further distribute the material or use it for any profit-making activity or commercial gain

If the publication is distributed under the terms of Article $25 \mathrm{fa}$ of the Dutch Copyright Act, indicated by the "Taverne" license above, 


\section{DE ROL VAN}

\section{ARBEIDSMARKTINFORMATIE IN DE OPLEIDINGSKEUZE VAN MBO'ERS}

ROA-R-2017/9

Didier Fouarge

Annemarie Künn-Nelen

Dijs Punt 


\section{Colofon}

(C) Researchcentrum voor Onderwijs en Arbeidsmarkt (ROA). Niets uit deze uitgave mag op enige manier worden verveelvoudigd zonder voorafgaande schriftelijke toestemming van de directeur van het ROA.

\section{Researchcentrum voor Onderwijs en Arbeidsmarkt}

School of Business and Economics

Maastricht University

email: secretary-roa-sbe@maastrichtuniversity.nl

website: www.roa.nl

\section{Redactie en productie}

Researchcentrum voor onderwijs en arbeidsmarkt (ROA)

\section{Vormgeving}

ROA secretariaat, Maastricht

ISBN: 978-90-5321-562-3

november 2017 


\section{INHOUD}

$01 \quad$ Inleiding

o2 Studiekeuzemodellen

O3 Data 9

04 Het gebruik en nut van informatiekanalen 11

$\begin{array}{ll}05 & 1 \text { Interesses, capaciteiten en carrièremogelijkheden }\end{array}$

$\begin{array}{ll}06 \text { Afwegingen in het studiekeuzeproces } & 19\end{array}$

07 Conclusie en discussie 25

Bijlage: Informatiekanalen, hun waarde en studiekeuzefactoren 27 



\section{SAMENVATTING}

De centrale vraag in dit rapport is in welke mate studiekiezers gebruik maken van arbeidsmarktinformatie bij het maken van hun opleidingskeuzes. In het bijzonder gaan wij in op de afruil tussen preferenties, competenties en arbeidsmarktperspectieven in het studiekeuzeproces. Dit rapport is opgesteld in het kader van het Project OnderwijsArbeidsmarkt.' Het doel van het POA is om de transparantie van de arbeidsmarkt te vergroten. De resultaten van dit onderzoek laten zich als volgt samenvatten:

- Veel factoren spelen een rol in de studie- en beroepskeuze van jongeren. Ten eerste spelen (academische) prestaties en verwachtingen ten aanzien van de eigen capaciteiten en de match met de voor de opleiding vereiste competenties een rol. Deze verwachtingen zijn zelf een functie van de sociale context (invloed van ouders en vrienden) en eerder opgedane ervaringen. Ten tweede kan de keuze voor een opleiding volgens de menselijk kapitaal theorie worden beschouwd als elke andere vorm van investeringen: een afweging tussen de kosten (tijd en geld dat in opleiding wordt geïnvesteerd) en de baten (kans op werk en loon) van de investering in een opleiding.

- Het studiekeuzeproces is niet altijd het resultaat van een rationele overweging die jongeren maken ten aanzien van wat zij met hun opleiding kunnen bereiken. Toch blijkt uit wetenschappelijke literatuur dat jongeren wel degelijk reageren op informatie over de arbeidsmarktkansen van opleidingen, en dat deze informatie de studiekeuze beïnvloedt. In de literatuur vinden wij aanwijzingen dat jongeren na informatieverschaffing: 1) hogere verwachtingen hebben over de opbrengsten van onderwijs; 2) een sterkere intentie om in het onderwijs te blijven; 3) vaker voor vervolgonderwijs kiezen; 4) specifieke opleidingen kiezen met goede perspectieven op werk en loon. Deze literatuur is echter nog schaars en de exacte grootte van het effect van arbeidsmarktinformatie op de studiekeuze verschilt tussen onderzoeken.

- Uit de literatuur blijkt dat het effect van arbeidsmarktinformatie op de studiekeuze verschilt naar sociale herkomst. Voor jongeren uit lage sociaaleconomische milieus geldt dat zij meer gevoelig zijn voor de gegeven arbeidsmarktinformatie, wellicht omdat bij hen de informatieachterstand groter is.

1 http://roa.sbe.maastrichtuniversity.nl/?portfolio=poa-project-onderwijs-arbeidsmarkt-2 
- Wij vinden dat in de studiekeuze van mbo'ers arbeidsmarktperspectieven op plek 3 staan, achter wat men leuk vindt en goed kan. Evengoed neemt bijna 50\% van de mbo'ers arbeidsmarktperspectieven mee in hun studiekeuze.

- Mbo'ers worden met name door hun ouders beïnvloed in hun studiekeuze. Ouders blijken vooral effectief in het in beeld brengen van wat de mbo'ers leuk vinden en goed kunnen. Decanen en mentoren scoren minder goed als het gaat om mbo'ers een goed beeld te geven van de carrièremogelijkheden van opleidingen.

- Eigen analyses op een speciale module van de mbo-monitor laten zien dat jongeren die carrièreperspectieven (heel) sterk hebben laten meewegen in hun keuze voor een mbo-opleiding een gunstigere arbeidsmarktsituatie hebben: ze hebben vaker werk, verdienen een hoger uurloon, hebben vaker werk op niveau en een betere aansluiting met de studierichting en zijn meer tevreden met hun functie/beroep. Ook rapporteren zij minder vaak spijt te hebben van hun opleidingskeuze.

- In een keuze-experiment (vignetstudie) waarin jongeren moesten kiezen tussen twee mbo programma's, gaan wij in op de afruil tussen preferenties, competenties en arbeidsmarktperspectieven. Onze analyses suggereren ten eerste dat jongeren gevoelig zijn voor de verwachte arbeidsmarktperspectieven van opleidingen bij het maken van hun keuze. Ten tweede komt naar voren dat het signaal 'slecht' (of het nu gaat op slecht passend bij interesses, of slechte arbeidsmarktkansen) een groter effect heeft op het niet kiezen voor een opleiding dan de tegenovergestelde boodschap 'goed' op de kans dat de opleiding wél gekozen wordt. Ten derde suggereren onze analyses dat studiekiezers bereid zouden zijn om te switchen van de opleiding van hun eerste voorkeur naar hun tweede voorkeur als de arbeidsmarktperspectieven voor de opleiding van hun tweede keuze beter zijn en als dit ze expliciet wordt verteld.

- De bevindingen in dit rapport suggereren dat jongeren, afgezien van de standaard loopbaanoriëntatie en -begeleiding (LOB) activiteiten die zij ondernemen, baat hebben van transparante arbeidsmarktinformatie over de arbeidsmarktkansen van opleidingen. 


\section{1 INLEIDING}

Scholieren van de middelbare school staan voor een zeer belangrijke beslissing: ze moeten de keuze maken voor een vervolgopleiding. Voor de meeste jongeren is deze keuze waarschijnlijk de belangrijkste 'carrière gerelateerde' beslissing tot op dat moment uit hun leven. Deze keuze bestaat grofweg uit twee stappen. Ten eerste is er de keuze voor een bepaald opleidingsniveau, waarbij de keuzemogelijkheden worden bepaald/ beperkt door het behaalde diploma uit het voortgezet onderwijs. Ten tweede moeten zij kiezen voor een bepaalde opleidingsrichting binnen dat niveau. Ook daar zijn eerder gemaakte keuzes (bijvoorbeeld profielkeuzes) vaak bepalend.

Er zijn veel factoren die een rol spelen in de studie- en beroepskeuze van jongeren. Verschillende studiekeuzemodellen komen aan bod in hoofdstuk 2. Belangrijke factoren die een rol spelen zijn ten eerste de academische prestaties en de eigen verwachtingen ten aanzien van de eigen capaciteiten en de match met het programma dat geboden wordt. Deze verwachtingen zijn zelf een functie van de sociale context (invloed van ouders en vrienden) ${ }^{2}$ en eerder opgedane ervaringen. ${ }^{3}$ Ten tweede kan de beslissing om aan een (vervolg)opleiding te beginnen volgens de menselijk kapitaal theorie worden beschouwd als elke andere vorm van investeringen: een afweging tussen de kosten en de baten van de investering in menselijk kapitaal. ${ }^{4}$ Het is een complex proces waarbij naast de vaste en opportuniteitskosten van het volgen van een opleiding- preferenties en interesses (wat wil ik?), competenties en capaciteiten (wat kan ik?) en arbeidsmarktperspectieven en loon na het afronden van de opleiding (wat kan ik ermee verdienen?) een belangrijke rol spelen in de kosten/baten afweging. ${ }^{5}$

Er is in Nederland veel informatie voorhanden over de kansen op de arbeidsmarkt naar opleiding. ${ }^{6}$ In een ideale situatie zouden jongeren voor een (vervolg)opleiding kiezen die'matcht' met hun individuele competenties en preferenties, maar ook goede arbeids-

Oxoby, R. (2014), Social inference and occupational choice: Type-based beliefs in a Bayesian model of class formation, Journal of Behavioral and Experimental Economics, 51, 30-37.

3 Meijers, F., Kuijpers, M. \& Winters, A. (2010), Leren kiezen / kiezen leren, Een literatuurstudie, ECBO.

4 Becker, G. (1962), Investment in human capital: A theoretical analysis, Journal of Political Economy, 70(5), 9-49. In de tekst gebruiken wij afwisselend de termen preferenties en interesses, en competenties en capaciteiten. De Keuzegidsen, Studiekeuze123, websites van S-BB en UWV en de publicatie Studie \& Werk van SEO zijn, naast de ROA rapporten en ArbeidsmarkInformatieSysteem, belangrijke bronnen van informatie. De pagina Studie in Cijfers behoort op de top 10 van de bezocht pagina's op de website van Studiekeuze123.nl. 
marktperspectieven biedt. Interesses, capaciteiten en arbeidsmarktperspectieven (in de vorm van verwacht inkomen) spelen volgens Wiswall en Zafar (2015) inderdaad een belangrijke rol in de studiekeuze, waarbij interesses het meest dominant zijn. De arbeidsmarktperspectieven zijn niet alleen afhankelijk van het onderwijsniveau, ${ }^{8}$ maar ook van de arbeidsvraag voor de gekozen richting. Door de onderwijsexpansie van de afgelopen decennia, kan zelfs worden gesteld dat het onderscheidend vermogen van jongeren en werkzoekenden steeds meer in de opleidingsrichting ligt. ${ }^{9}$

De centrale vraag in dit rapport is in welke mate studiekiezers gebruik maken van arbeidsmarktinformatie bij het maken van hun opleidingskeuzes. In het bijzonder gaan wij in op de afruil tussen preferenties, competenties en arbeidsmarktperspectieven in het studiekeuzeproces. Dit doen wij aan de hand van een overzicht van de literatuur en een onderzoek onder mbo-gediplomeerden naar de overwegingen die zij zelf hebben gemaakt in hun keuze voor een mbo-opleiding. Als onderdeel van dat onderzoek is tevens een keuze-experiment uitgevoerd (vignetstudie) waarin de afruil tussen preferenties, competenties en arbeidsmarktperspectieven wordt gekwantificeerd. Met dit onderzoek willen we achterhalen in welke mate jongeren goed geïnformeerde keuzes maken en of ze baat hebben bij een transparante arbeidsmarkt. Door het gedrag van studiekiezers te analyseren, kunnen we onze kennis over hun studiekeuzeproces verbeteren. Hoewel er veel factoren een rol spelen in de studiekeuze, leggen wij in het vervolg dus vooral de nadruk op de rol van arbeidsmarktinformatie in dit proces.

Een goed geïnformeerde studiekeuze is van belang op micro/individueel niveau, maar ook op macro/maatschappelijk niveau. Op microniveau zorgt een optimale/succesvolle studiekeuze, onder andere, voor betere arbeidsmarktuitkomsten in de vorm van een grotere kans op werk en een hoger salaris. Verder zorgt een beter geïnformeerde studiekeuze voor minder spijt onder studenten, stellen onderzoekers. ${ }^{10}$ Daarnaast stelt het Ministerie van OCW dat een gedegen loopbaanoriëntatie en -begeleiding studenten een realistischer beeld van de inhoud van opleidingen en beroepen kan bieden, alsook van de arbeidsmarktperspectieven voor deze opleidingen en beroepen." Dit kan leiden tot minder 'verkeerde' studiekeuzes als gevolg van gebrek aan informatie, meer gelijke kansen in het onderwijs en betere arbeidsmarktperspectieven voor studenten. Op macroniveau kan een optimalere studiekeuze zorgen voor een betere aansluiting tussen

7 Wiswall, M. \& Zafar, B. (2015a), Determinants of college major choice: Identification using an information experiment, Review of Economic Studies, 82, 791-824.

8 Hartog, J. (2000), Over-education and earnings: where are we, where should we go?, Economics of Education Review, 19(2), 131-147.

9 Altonji, Arcidiacono, Maurel (2015), The analysis of field choice in college and graduate school: Determinants and wage effects, NBER No. w21655.

10 Borghans, L., Coenen, J., Golsteyn, B., Huijgen, T., \& Sieben, I. (2008), Voorlichting en begeleiding bij de studieen beroepskeuze en de rol van arbeidsmarktinformatie, Researchcentrum voor onderwijs en arbeidsmarkt, Maastricht.

11 Kamerbrief over loopbaanoriëntatie en loopbaanbegeleiding, 28 september 2016 (https://www.rijksoverheid.nl/documenten/kamerstukken/2016/o9/28/kamerbrief-over-loopbaanorientatie-en-loopbaanbegeleiding). 
vraag en aanbod op de arbeidsmarkt. ${ }^{12}$ Wiswall en Zafar $(2015)^{13}$ stellen dat dit kan leiden tot positieve welvaartseffecten. De werkloosheid kan bijvoorbeeld door beter geïnformeerde keuzes lager uitpakken, en de capaciteiten van de beroepsbevolking kunnen beter worden benut.

Dit rapport is als volgt opgebouwd. In hoofdstuk 2 bespreken we de bestaande studiekeuzemodellen en geven we een beknopt overzicht van de literatuur over het onderzoek naar de rol van arbeidsmarktinformatie in de studiekeuze. Daarna introduceren we in hoofdstuk 3 ons eigen onderzoek naar de studiekeuze onder mbo-studenten. In hoofdstuk 4 bespreken we, aan de hand van onze data, de informatiebronnen die mbo-studenten gebruiken bij hun opleidingskeuze en wat ze hieruit hebben geleerd. Vervolgens voeren we, in hoofdstuk 5 , analyses uit met betrekking met de eigen overwegingen bij de opleidingskeuze. In hoofdstuk 6 voeren we een opleidingskeuze-experiment (vignet-analyse) uit. Hoofdstuk 7 concludeert.

12 Arcidiacono, P., Hotz, V. J., \& Kang, S. (2012), Modelling college major choices using elicited measures of expectations and counterfactuals, Journal of Econometrics, 166(1), 3-16. Borghans, L. \& Coenen, J. (2007), Arbeidsmarkt en studiekeuze van jongeren, In: De arbeidsmarkt naar opleiding en beroep tot 2012, Researchcentrum voor Onderwijs en Arbeidsmarkt, Universiteit Maastricht.

13 Wiswall, M. \& Zafar, B. (2015a), Determinants of college major choice: Identification using an information experiment, Review of Economic Studies, 82, 791-824. 



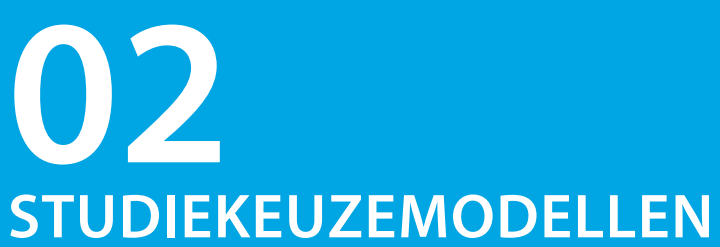

Het essentiële belang van de studiekeuze wordt breed onderkend. Er zijn dan ook verscheidene wetenschappelijke studiekeuzemodellen ontwikkeld. Fouarge et al. $(2016)^{14}$, waarop dit hoofdstuk is gebaseerd, onderscheiden drie belangrijke modelvormen binnen de wetenschappelijke studiekeuzetheorie:

- Economische modellen (naar micro-economische traditie)

- Statusverwervingsmodellen (naar sociologische traditie)

- combinatiemodellen (combinatie van bovenstaande twee modellen)

\section{Economische modellen}

Economische studiekeuzemodellen gebruiken het 'standaard' (micro-) economisch, theoretisch kader. Deze modellen veronderstellen dat studiekiezers rationele agenten zijn die de kosten en baten ${ }^{15}$ van een bepaalde studie tegen elkaar afwegen. De studiekeuze wordt weergegeven als een optimaliserings-/maximalisatie vraagstuk. Volgens deze theorie zullen jongeren de studie prefereren waarbij het verschil tussen (financiële) baten en de (financiële) kosten het hoogst is. Economische studiekeuzemodellen gebruiken de theorie van menselijk kapitaal. Dit menselijk kapitaal bestaat uit de kennis, vaardigheden en andere karakteristieken van een individu. Volgens Becker (1994) ${ }^{16}$ verhoogt (formeel) onderwijs de waarde van het menselijk kapitaal van individuen. Door deze verhoging van het menselijk kapitaal, worden de (arbeids-)productiviteit alsook de inkomens verhoogd. ${ }^{17}$ Becker (1994) stelt dat onderwijs (een van) de belangrijkste investering(en) is in menselijk kapitaal. In ons onderzoek maken we (voornamelijk) gebruik van het theoretisch kader van deze economische studiekeuzemodellen.

14 Dit hoofdstuk is gebaseerd op Fouarge. D., Künn-Nelen, A. \& Mommers, A. (2016), Studiekeuze en arbeidsmarkt: literatuurstudie, Maastricht: ROA-R-2016/3.

15 Deze kosten en baten kunnen zowel financieel (studiekosten, verhoogd toekomstig inkomen), als niet financieel (inspanning, studieplezier, status) zijn.

16 Becker, G. (1994), Human Capital: A Theoretical and Empirical Analysis, with Special Reference to Education, 15-28 (3rd edition), The University of Chicago Press.

17 Becker (1994) stelt dat er veel studies, voor veel landen, zijn die empirisch bewijs leveren voor de stelling dat onderwijs productiviteit en inkomens verhoogt. 


\section{Statusverwervingsmodellen}

Statusverwervingsmodellen komen voort uit de sociologische wetenschap. In tegenstelling tot de economische studiekeuzemodellen, gaan deze modellen minder uit van een 'rationele' beslissing op een specifiek moment. Daarentegen, leggen statusverwervingsmodellen de nadruk op de levenslange invloed van sociale herkomst. ${ }^{18}$ Volgens deze theorie, bepaalt sociaaleconomische herkomst voor een groot deel welke (studie) mogelijkheden jongeren hebben. De sociale context (de mensen in iemands' omgeving) 'vormt' personen gedurende hun gehele leven, en speelt daardoor een belangrijke rol bij de studiekeuze.

Volgens Sewell en Shah (1968) $)^{19}$ hebben sociaaleconomische status, intelligentie en aanmoediging vanuit de ouders alle drie een belangrijke rol in de studiekeuze van jongeren. Ze betogen dat de waargenomen studiekeuzes alleen kunnen worden verklaard door de gezamenlijke invloed van deze drie factoren.

\section{Combinatiemodellen}

Beide bovenstaande modellen hebben sterke en zwakke punten. Economische modellen die de studiekeuze in een formeel, kwantitatief optimalisatiekader weergeven, geven wellicht te weinig aandacht aan andere (sociaaleconomische) factoren. Statusverwervende modellen schenken, daarentegen, wel veel aandacht aan sociaaleconomische factoren. Deze modellen laten echter na om de studiekeuze in een kwantificeerbaar theoretisch kader weer te geven.

Inspelend hierop, zijn er een aantal studiekeuzemodellen opgesteld die de sterke kanten van zowel de economische als de sociologische traditie combineren. Deze combinatiemodellen veronderstellen dat de studiekeuze zowel een rationeel kosten-baten component (micro-economisch) als een statusverwervend (sociologisch) component bevat. Uit deze modellen blijkt dat er een veelheid aan factoren/bronnen is die van belang zijn bij de studiekeuze. Vrontis et al. (2007) $)^{20}$ onderscheiden vier sets van determinanten: individuele determinanten, contextuele determinanten, karakteristieken van de school waar men vandaan komt en karakteristieken van de school en opleiding waar men instroomt:

- Individuele determinanten hebben betrekking op persoonlijke eigenschappen (geslacht, sociale herkomst, etc.), cognitieve en psychologische kenmerken, voorkeuren, verwachtingen over inkomen en niet monetaire aspecten van de studiekeuze zoals de verwachte slaagkans.

18 Maniu, I. \& Maniu, C. (2014), A model of students' university decision-making behavior, SEA - Practical Application of Science, 3(5), 431-436.

19 Sewell, W. \& Shah, V. (1968), Social class, parental encouragement, and educational aspirations, American Journal of Sociology, 73(5), 559-572.

20 Vrontis, D., Thrassou, A. \& Melanthiou, Y. (2007), A contemporary higher education student-choice model for developed countries, Journal of Business Research, 60, 979-989. 
- Contextuele determinanten hebben betrekking op de economische situatie, het beleid met betrekking tot toelatingseisen en studiefinanciering, en de rol van externe beïnvloeders zoals familie, vrienden, media en studieadviseurs.

- Kenmerken van de school waar men vandaan komt hebben betrekking op compositie van de school en het aangeboden curriculum.

- Karakteristieken van de school en opleiding waar men instroomt hebben betrekking op locatie, toelatingseisen, de uitstraling van de school, gebouwen, en natuurlijk het opleidingsaanbod en de kwaliteit ervan.

\section{Eerder onderzoek}

Er wordt in Nederland veel energie besteed aan het maken van arbeidsmarktinformatie. Enkele voorbeelden zijn: Studie in cijfers (Studiekeuze123.nl voor het hoger onderwijs) en de Keuzegids (Keuzegids.org voor mbo en hoger onderwijs). Het is echter de vraag in welke mate jongeren gebruik maken van dergelijke informatie, en of het van invloed is op hun studiekeuze. In Fouarge e.a. (2016) doen wij uitgebreid verslag van het wetenschappelijk onderzoek dat ingaat op de rol van arbeidsmarkinformatie in de opleidings- en studiekeuze. ${ }^{21}$ Uit onderzoek blijkt dat de beschikbaarheid van arbeidsmarktinformatie naar opleiding en beroep de transitie van school naar werk voor jongeren verbetert. ${ }^{22}$ Bovendien blijkt uit analyses van het ROA Schoolverlatersonderzoek dat studieloopbaanbegeleiding op school tot betere studiekeuzes leidt. ${ }^{23}$

Er zijn ook enkele wetenschappelijke experimenten uitgevoerd waarin de effecten van het geven van arbeidsmarktinformatie aan jongeren op hun (voorgenomen) studiekeuze is onderzocht. De effectiviteit van het geven van informatie is echter niet eenduidig: soms worden er zeer sterke effecten gevonden, ${ }^{24}$ soms zwakke. ${ }^{25}$ Hoewel de effectiviteit van de informatieverschaffing verschilt van studie tot studie, worden in de meeste experimenten wel degelijk (in meer of mindere mate) effecten gevonden. Er volgt bijvoorbeeld dat jongeren na informatieverschaffing: 1) hogere verwachtingen hebben over de opbrengsten van onderwijs; 2) een sterkere intentie hebben om in het onderwijs te blijven; 3) vaker voor vervolgonderwijs kiezen; 4) specifieke opleidingen kiezen met goede perspectieven op werk en loon.

Er zijn dus wel degelijk goede indicaties dat jongeren reageren op informatie, waarbij deze vatbaarheid vaak verschilt naar sociale herkomst. Voor jongeren uit lage sociaaleconomische milieus geldt dat over het algemeen dat zij meer gevoelig zijn voor de

21 Fouarge, D., Künn-Nelen, A., \& Mommers, A. (2016), Studiekeuze en arbeidsmarkt: literatuurstudie, Maastricht: ROA-R-2016/3. Zie ook het overzicht van de literatuur: French en Oreopoulos (2017), Behavioral barriers transitioning to college, Labour Economics, forthcoming.

22 Saniter, N., \& Siedler, T. (2014), The effects of occupational knowledge: job information centers, educational choices, and labor market outcomes, Bonn: IZA DP 8100.

23 Borghans, L., Golsteyn, B. \& Stenberg, A. (2015), Does Expert Advice Improve Educational Choice? PloS one, 10(12), e0145378.

24 Oreopoulos, P. \& Dunn, R. (2013), Information and college access: Evidence from a randomized field experiment, The Scandinavian Journal of Economics, 115(1), 3-26.

25 Kerr, S., Pekkarinen, T., Sarvimäki, M. \& Uusitalo, R. (2014), Educational choice and information on labor market prospects: $A$ randomized field experiment, Working Paper. 
gegeven arbeidsmarktinformatie. ${ }^{26}$ Dat zij meer baat hebben van informatie kan komen doordat zij een grotere informatieachterstand hebben. ${ }^{27}$

Ook het geven van informatie aan ouders, die in de studiekeuze van hun kinderen een belangrijk rol spelen, kan van invloed zijn. Zo laat experimenteel onderzoek zien dat kinderen van ouders die geïnformeerd zijn over het belang van wiskunde en natuurkunde in het dagelijks leven deze vakken op school langer blijven volgen. ${ }^{28}$

26 Hoxby, C., \& Turner, S. (2013), Expanding college opportunities for high-achieving, low income students, Stanford Institute for Economic Policy Research Discussion Paper, (12-014).

27 Wiswall, M., \& Zafar, B. (2015b), How do college students respond to public information about earnings? Journal of Human Capital, 9(2), 117-169.

28 Harackiewicz, J., Rozek, C., Hulleman, C., \& Hyde, J. (2012), Helping parents to motivate adolescents in mathematics and science an experimental test of a utility-value intervention, Psychological Science, 23(8), 899-906. 


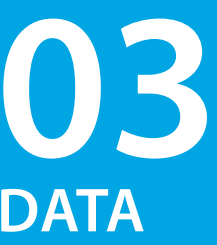

Voor onze empirische analyses maken wij gebruik van een supplement op de 2015 BVE-monitor van het Researchcentrum voor Onderwijs en de Arbeidsmarkt (ROA), ${ }^{29}$ een onderzoek onder mbo-gediplomeerden. Gediplomeerden uit het mbo zijn in 2015, ongeveer anderhalf jaar na het behalen van hun diploma (in 2013/2014), benaderd met een reeks vragen met betrekking tot de aansluiting onderwijs-arbeidsmarkt. In het najaar van 2016 zijn respondenten die hiervoor aan ROA toestemming hebben gegeven opnieuw benaderd met een vragenlijst gericht op de door hen gebruikte informatiebronnen bij het maken van hun eigen opleidingskeuze, met een nadruk op de mate waarin deze gediplomeerden gebruik hebben gemaakt van arbeidsmarktinformatie bij het maken van hun opleidingskeuze. Daarnaast bevatte de vragenlijst een keuze-experiment waarin respondenten gevraagd zijn om vmbo'ers te adviseren bij een keuze tussen twee mbo-opleidingen. ${ }^{30}$

Voor ons onderzoek gebruiken we alleen de antwoorden van mbo-bol gediplomeerden uit de niveaus 2, 3 en 4 met een maximale leeftijd van 25 jaar ten tijde van diplomering. Wij nemen aan dat de mbo-studie voor deze groep studenten een initiële onderwijskeuze betreft. Deze subgroep bestaat dus uit 'typische' mbo-studenten, de groep waarvan we de studiekeuze willen onderzoeken. We nemen hierbij aan dat mbo-studenten die ouder zijn dan 25 jaar hun studie hebben gevolgd met een meer bewuste carrière overweging. Wij minimaliseren hiermee de kans op positieve relaties tussen arbeidsmarktinformatie en opleidingskeuze. Aan de 2015 BVE monitor deden 17.974 mbo'ers mee die aan deze selectie voldoen, waarvan ruim 61\% (9.009) toestemming hebben gegeven voor vervolgonderzoek, maar voor een deel daarvan bleek het e-mailadres dat opgegeven is voor vervolgmeting niet bruikbaar. ${ }^{31} 2.913$ van hen zijn aan de survey begonnen en 2.489 hebben deze afgemaakt. ${ }^{32}$

29 http://roa.sbe.maastrichtuniversity.nl/?portfolio=school-leaver-surveys

30 In onze data is geen informatie beschikbaar over de sociaaleconomische status van de ouders.

31 Vrouwen en mbo'ers van 22 jaar en ouder blijven vaker bereid om mee te willen doen aan een vervolgenquête. Gediplomeerden uit mbo-niveau 2 blijken minder vaak bereid om mee te willen doen aan een vervolgenquête.

32 Mbo 2 gediplomeerden hebben een grotere kans op non-respons en maken de survey minder vaak af als zij er aan begonnen. Vrouwen hebben juist een grotere kans op respons en maken de survey vaker helemaal af. Leeftijd is niet gerelateerd aan de respons en het wel of niet afmaken van de survey. 



\section{4 \\ HET GEBRUIK EN NUT VAN INFORMATIEKANALEN}

\section{Informatiekanalen bij keuze van opleiding}

In het supplement aan de mbo-monitor vragen wij aan de recent gediplomeerden terug te kijken naar hun eigen studiekeuze. Meer specifiek vragen wij ze terug te denken aan de gebruikte informatiekanalen en wat voor informatie zij uit de betreffende kanalen hebben gehaald. De informatiekanalen die wij onderscheiden zijn afgeleid uit de vmboen vo-monitor. Wij vragen: "Welke informatiebron(nen) heb je toen gebruikt om jouw keuze voor deze mbo-opleiding te maken? (meerdere antwoorden mogelijk)", en onderscheiden tien informatiekanalen:

- Gesprekken met docent/decaan/mentor van mijn vooropleiding

- Voorlichtingsdagen georganiseerd door mijn vooropleiding

- Voorlichtingsdagen georganiseerd door mijn mbo-opleidingen

- Meeloopdagen bij mbo-opleidingen

- Websites van mbo-opleidingen

- Algemene website over studiekeuze en beroepsvoorlichting

- Bezoek aan landelijke of regionale studiebeurs

- Folders, brochures, e.d.

- Gesprekken met familie en/of vrienden

- Overige bronnen

Hoewel wij het hier hebben over informatiekanalen, bevat deze lijst ook doe-activiteiten (bijvoorbeeld meeloopdagen en bezoek aan voorlichtingsdagen) waar scholieren iets uit kunnen leren over de inhoud van de opleiding en de mate waarin het aansluit bij de interesses en capaciteiten.

In figuur 1 wordt weergegeven welk percentage van de mbo-gediplomeerden gebruik heeft gemaakt van de 10 door ons onderscheiden informatiekanalen. ${ }^{33}$

33 Zie de bijlage voor vergelijkbare figuren naar mbo-richting en -niveau. 


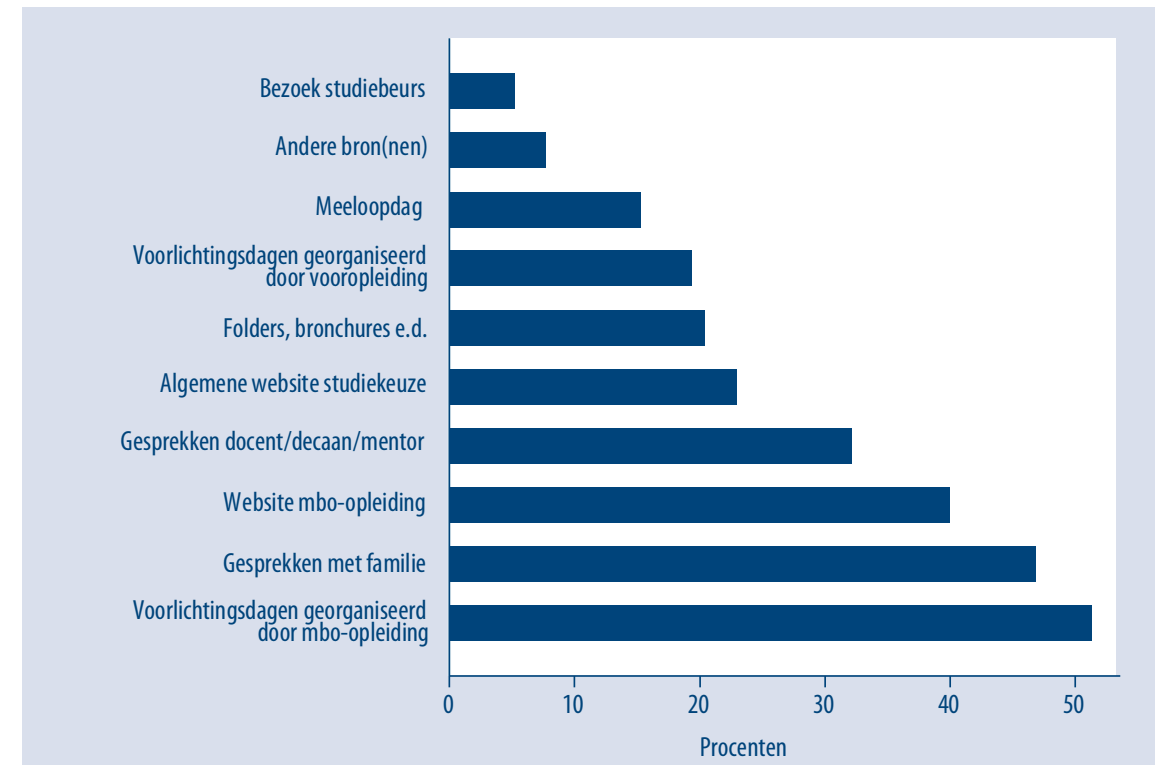

Bron: ROA, Transparante arbeidsmarkt 2016

Van de gediplomeerden is $51 \%$ naar (ten minste) een voorlichtingsdag van een mboopleiding geweest. Daarmee is dit het meest gebruikte informatiekanaal. $47 \%$ van de gediplomeerden heeft gesprekken met familie en/of vrienden gebruikt als informatiebron voor de studiekeuze, waarmee het de op een na meest gebruikte informatiebron is. Dat deze twee informatiebronnen het meest gebruikt worden, komt overeen met de bevindingen uit de vo-monitor. ${ }^{34}$ Verder, heeft $40 \%$ van de gediplomeerden gebruik gemaakt van de website van een mbo-opleiding en $32 \%$ heeft gesproken met een docent, decaan en/of mentor. De overige informatiebronnen zijn allen door minder dan $25 \%$ van de gediplomeerden gebruikt.

\section{Nut van informatiekanalen}

Voor maximaal drie van de hierboven beschreven informatiekanalen (gesprekken met docent/decaan/mentor van mijn vooropleiding, voorlichtingsdagen georganiseerd door mijn mbo-opleidingen, gesprekken met familie en/of vrienden) vragen wij, indien van toepassing, door aan de hand van een aantal stellingen wat voor soort informatie studenten uit deze bronnen halen.

De reden dat we focussen op informatiebron voorlichtingsdagen georganiseerd door mijn mbo-opleidingen en gesprekken met familie en/of vrienden is dat deze twee bronnen volgens de vo-monitor het vaakst genoemd/gebruikt worden. Het laat

34 ROA (2016), Schoolverlater tussen onderwijs en arbeidsmarkt 2015, Maastricht: ROA-R-2016/2. 
hiermee zien dat vrienden en familie een belangrijke invloed hebben op de studiekeuze. Gesprekken met docent/decaan/mentor worden uitgelicht als relevante informatiebron omdat Borghans et al. (2015) aantonen dat studenten die gebruik maken van deze bron(nen) minder vaak spijt hebben van hun studiekeuze. ${ }^{35}$ We onderzoeken de bruikbaarheid van deze drie informatiebronnen. Daarbij leggen we de focus op de kwaliteit van de informatie die wordt gegeven over de drie door ons gedefinieerde essentiële studiekeuzefactoren: interesses, capaciteiten, en arbeidsmarktperspectieven.

Wij vragen in hoeverre de respondent het eens is met een aantal stellingen over het gesprek/de voorlichtingsdag ${ }^{36}$ (op een schaal van $1=$ helemaal mee oneens tot $5=$ helemaal mee eens):

- Het gesprek/de voorlichtingsdag heeft me een goed beeld gegeven van wat ik leuk vond

- Het gesprek/de voorlichtingsdag heeft me een goed beeld gegeven van wat ik kon

- Het gesprek/de voorlichtingsdag heeft me een goed beeld gegeven van de gekozen mbo-opleiding

- Het gesprek/de voorlichtingsdag heeft me een goed beeld gegeven van de gekozen mbo instelling

- Het gesprek/de voorlichtingsdag heeft me een goed beeld gegeven van de carrièremogelijkheden van de gekozen mbo-opleiding

- Het gesprek/de voorlichtingsdag heeft mijn studiekeuze beïnvloed

- Het gesprek/de voorlichtingsdag heeft mijn instellingskeuze beïnvloed

Figuur 2 geeft procentueel weer hoeveel mbo-gediplomeerden het eens zijn met deze stellingen m.b.t. de waarde van de informatiebronnen bij het maken van hun opleidingskeuze. ${ }^{37}$ Wat men vooral haalt uit gesprekken met docent/decaan/mentor is informatie over wat men leuk vind en waar men goed in is. Ten opzichte van de andere twee uitgelichte informatiebronnen, is het percentage (helemaal) mee eens dat gesprek(ken) met docent/decaan/mentor een goed beeld van wat studenten leuk vinden (preferenties, 58\%), en van hun carrièremogelijkheden (46\%) lager. Daarnaast, hebben dit soort gesprekken relatief minder vaak direct invloed op de studiekeuze (40\%).

35 Waarom is echter niet duidelijk. Het zou kunnen dat de docent/decaan nuttige tips geeft of bijdraagt aan een beter zelfbeeld. Dat zoeken wij hier uit.

36 De stellingen zijn in meervoud geformuleerd indien er meerdere gesprekken hebben plaatsgevonden of meerdere voorlichtingsdagen bezocht zijn.

37 De overeenkomstige figuren naar de verschillen per mbo-richting en -niveau zijn te vinden in de bijlage. 
FIGUUR 2 Waarde van informatiekanalen bij opleidingskeuze

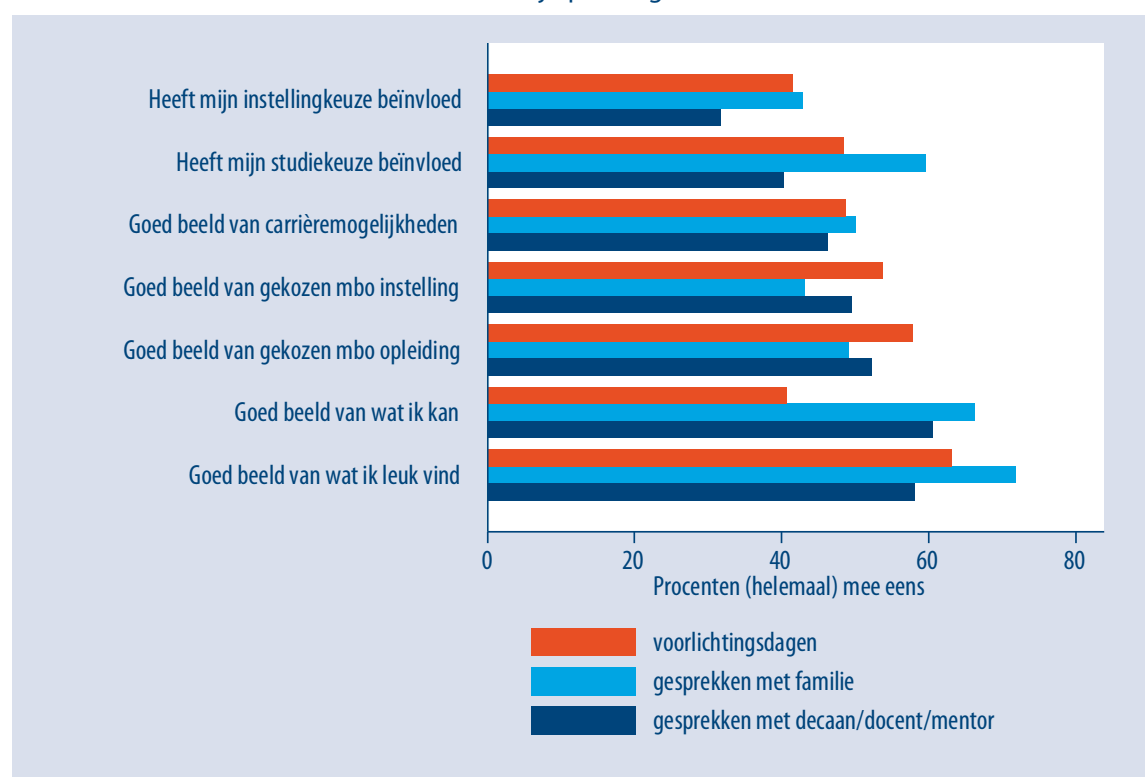

Bron: ROA, Transparante arbeidsmarkt 2016

Voorlichtingsdagen van mbo-opleidingen geven een relatief goed beeld van de mboopleiding (58\%) en van de mbo-instelling (54\%).Verder geeft $63 \%$ van de gediplomeerden aan dat deze voorlichtingsdagen een goed beeld gaven van wat ze leuk vonden, $49 \%$ kreeg een goed beeld van de carrièremogelijkheden, en bij $48 \%$ van de gediplomeerden hadden deze voorlichtingsdagen invloed op de studiekeuze. Voorlichtingsdagen van mbo-opleidingen helpen, ten opzichte van de andere uitgelichte informatiebronnen, minder vaak om een goed beeld te vormen van waar studenten goed in zijn (41\%).

Ten opzichte van de andere informatiebronnen geven meer mbo-gediplomeerden aan dat gesprekken over de studiekeuze met familie en/of vrienden een goed beeld geven van wat zij leuk vinden (preferenties) en van wat ze kunnen (capaciteiten). $72 \%$ van de gediplomeerden geeft aan dat deze informatiebron een goed beeld geeft hun preferenties. $66 \%$ geeft aan dat deze gesprekken een goed beeld geven van hun capaciteiten. Verder hebben gesprekken met familie en/of vrienden ook de meeste invloed op de studiekeuze (60\%). Ongeveer 50\% geeft aan dat deze gesprekken een goed beeld gaven van hun carrièremogelijkheden. 


\section{5 \\ INTERESSES, CAPACITEITEN EN CARRIËREMOGELIJKHEDEN}

\section{Overwegingen bij studiekeuze}

De studiekeuze is een complex proces, waarin talloze factoren meespelen. Om deze keuze beter inzichtelijk te maken hebben wij aan mbo-gediplomeerden gevraagd in welke mate zij de volgende 3 aspecten hebben meegewogen in hun opleidingskeuze: 1) wat ze leuk vinden, 2) waar ze goed in zijn en 3) de carrièremogelijkheden van de opleiding. Voor iedere factor konden de mbo-gediplomeerden op een schaal van 1 (helemaal niet meegewogen) tot 5 (heel sterk meegewogen) aangeven in welke mate zij de aspecten hebben meegewogen bij hun opleidingskeuze. Figuur 3 laat voor elk van deze 3 aspecten het percentage van de mbo-gediplomeerden zien, dat het betreffende aspect (heel) sterk heeft meegewogen (waarde 4 of 5 op de antwoordschaal). ${ }^{38}$

\section{FIGUUR 3 Aspecten die meegewogen zijn in de opleidingskeuze van mbo'ers}

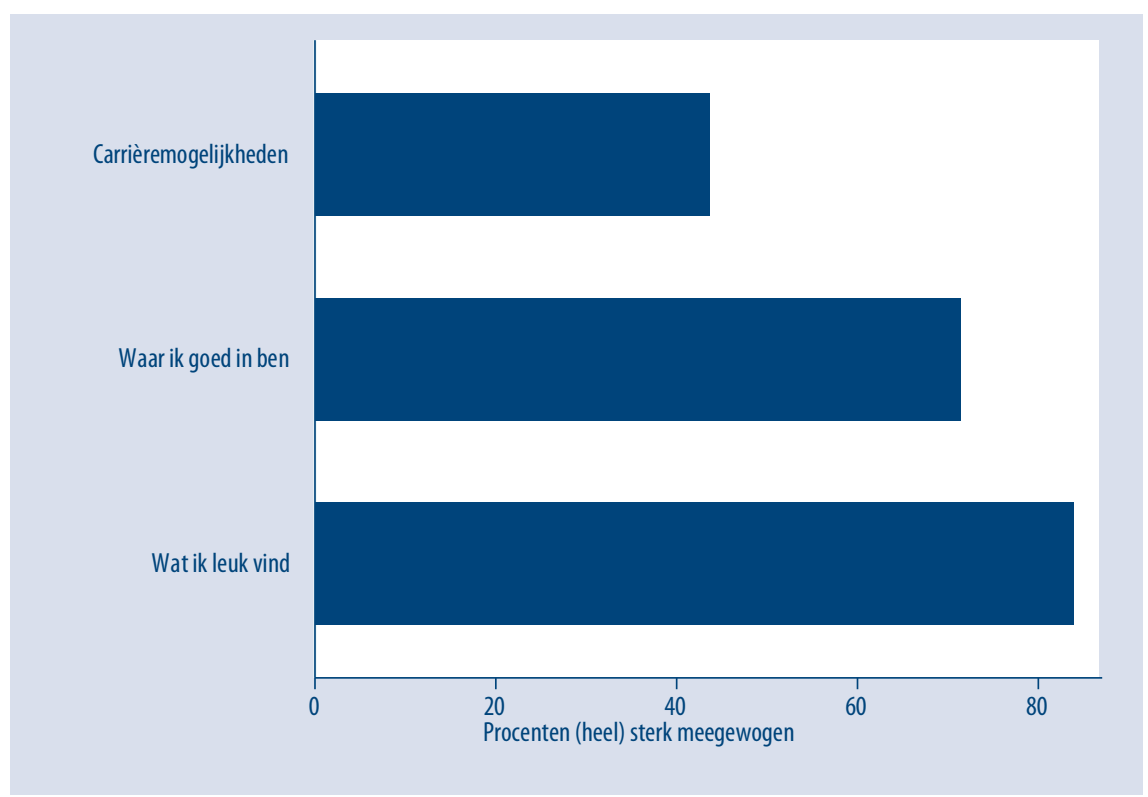

38 De overeenkomstige figuren naar opleidingsrichting en -niveau zijn weergegeven in de bijlage. 
In de eerste plaats laten mbo'ers hun preferenties prevaleren bij het maken van hun opleidingskeuze: $84 \%$ van de mbo-gediplomeerden geeft aan dat 'wat ik leuk vind' (heel) sterk heeft meegewogen. In de tweede plaats (71\%) laten scholieren de persoonlijke capaciteiten meewegen in de studiekeuze. In de laatste plaats tellen de carrièremogelijkheden die gepaard gaan met een opleiding mee: $44 \%$ van de gediplomeerden geeft aan dat ze carrièremogelijkheden (heel) sterk hebben laten meewegen in de studiekeuze. ${ }^{39}$

\section{Relatie tussen overwegingen en arbeidsmarktuitkomsten}

Wij relateren de 3 hierboven besproken keuzefactoren aan het eigen arbeidsmarktsucces bij intrede op de arbeidsmarkt. Hierdoor kunnen we onderzoeken in welke mate er sprake is van een relatie tussen de overwegingen bij de studiekeuze en de arbeidsmarktuitkomsten na het behalen van een diploma. Hierbij relateren we de mate waarin de 3 besproken overwegingen in de studiekeuze hebben meegespeeld aan een aantal relevante arbeidsmarktuitkomsten:

1. Het niet hebben van werk: een binaire variabele die een waarde van 1 heeft als iemand geen betaald werk heeft ten tijde van de 2016 survey, en ook niet bezig is met een vervolgstudie.

2. Het uurloon: logaritme van het bruto uurloon (maandelijkse salaris gedeeld door het aantale gewerkte uren per maand) dat respondenten met werk verdienden ten tijde van de 2016 survey.

3. Het hebben van werk buiten het eigen domein: een binaire variabele die een waarde van 1 heeft als iemand werk heeft dat niet direct gerelateerd is aan de gevolgde mbo-opleiding (werk buiten domein). Het gaat hier om het oordeel van de respondent over zijn/haar werk. Deze variabele is in de 2015 survey gemeten.

4. Onderbenutting: een binaire variabele die een waarde van 1 heeft als iemand werk heeft onder het eigen niveau. Het gaat hier om het oordeel van de respondent over zijn/haar werk. Deze variabele is in de 2015 survey gemeten.

5. Tevredenheid met werk: het gaat hier om de satisfactie met het eigen werk, gemeten op een schaal van 1 ('zeer ontevreden') tot en met 5 ('zeer tevreden'). Deze variabele is in de 2016 survey gemeten.

6. Spijt van de studiekeuze: een binaire variabele die een waarde van 1 heeft als iemand achteraf aangeeft dat hij/zij niet meer voor dezelfde opleiding zou willen kiezen. Deze variabele is in de 2015 survey gemeten.

De uitkomsten van de regressieanalyses zijn weergegeven in tabel 1. Naarmate jongeren in sterkere mate voor hun opleiding hebben gekozen vanuit het perspectief van wat zij leuk vinden, verdienen zij een hoger uurloon en is de tevredenheid met hun functie en beroep hoger. Ze zijn tevens minder vaak werkzaam buiten hun domein en onder hun

39 De drie keuzefactoren zijn positief met elkaar gecorreleerd, waarbij de correlatie tussen 'waar ik goed in ben' en 'wat ik leuk vind' de sterkste is (0.36). De correlatie tussen 'wat ik leuk vind' en 'carrièremogelijkheden' bedraagt 0.12 , en dat tussen 'waar ik goed in ben' en 'carrièremogelijkheden' bedraagt 0.10. 
niveau, en ervaren minder spijt van het opleidingskeuze. Waar men goed in is lijkt een kleinere rol te spelen in de arbeidsmarktuitkomsten, hetgeen mogelijk het gevolg is van de correlatie tussen de keuzefactoren 'wat ik leuk vind' en 'wat ik kan'40 Wel is het zo dat jongeren die aangeven hun opleiding te hebben gekozen vanuit het perspectief van wat zij kunnen een hoger uurloon verdienen.

De carrièreperspectieven spelen na controle voor wat men leuk vindt en waar men goed in is, een significante rol in de arbeidsmarktuitkomsten van recent mbo gediplomeerden. Naarmate jongeren hun carrièreperspectieven in sterkere mate hebben laten meewegen in hun studiekeuze zitten ze minder vaak zonder werk, en als ze werk hebben is dit vaker in de eigen richting en op het eigen niveau. Ze verdienen een hoger uurloon, zijn vaker tevreden met hun functie/beroep en hebben minder vaak spijt van hun studiekeuze. Om een idee te geven van de omvang van de gevonden relaties: het uurloon is $7 \%$ hoger voor mbo'ers die aangeven carrièreperspectieven (heel) sterk te hebben meegewogen in hun keuze voor een opleidingsrichting vergeleken met mbo'ers die de carrièremogelijkheden nauwelijks of niet hebben laten meewegen. Voor mbo'ers die aangeven dat wat zij leuk vinden (heel) sterk hebben meegewogen, is het uurloon $6 \%$ hoger en voor mbo' ers die aangeven waar zij goed in zijn (heel) sterk te hebben meegewogen is het uurloon $4,5 \%$ hoger. Wij kunnen hieruit niet concluderen dat er een causaal verband is tussen de variabelen. Echter, zowel voor uurloon als voor werk buiten de richting en onder het niveau geldt dat de relatie sterker is met carrièremogelijkheden dan met wat men leuk vindt.

TABEL 1 Relatie tussen overwegingen bij opleidingskeuze en arbeidsuitkomsten

\begin{tabular}{|c|c|c|c|c|c|c|}
\hline & (1 & (2) & (3) & (4) & (5) & (6) \\
\hline & Geen werk & Uurloon (log) & $\begin{array}{l}\text { Werk buiten } \\
\text { vakrichting }\end{array}$ & $\begin{array}{c}\text { Onder- } \\
\text { benutting }\end{array}$ & $\begin{array}{l}\text { Tevredenheid } \\
\text { met functie/ } \\
\text { beroep }\end{array}$ & Spijt \\
\hline \multirow[t]{2}{*}{ Wat ik leuk vind } & $-0,014$ & $0,062^{* *}$ & $-0,097^{* *}$ & $-0,064^{*}$ & $0,370^{* * *}$ & $-0,156^{* * *}$ \\
\hline & $(0,021)$ & $(0,029)$ & $(0,038)$ & $(0,036)$ & $(0,089)$ & $(0,022)$ \\
\hline \multirow[t]{2}{*}{ Wat ik kan } & $-0,004$ & $0,045^{*}$ & $-0,024$ & $-0,005$ & 0,085 & 0,001 \\
\hline & $(0,018)$ & $(0,025)$ & $(0,030)$ & $(0,029)$ & $(0,072)$ & $(0,019)$ \\
\hline \multirow[t]{2}{*}{ Carrièremogelijheden } & $-0,036^{* *}$ & $0,069^{* * *}$ & $-0,153^{* * *}$ & $-0,116^{* * *}$ & $0,175^{* * *}$ & $-0,092^{* * *}$ \\
\hline & $(0,016)$ & $(0,020)$ & $(0,026)$ & $(0,025)$ & $(0,059)$ & $(0,017)$ \\
\hline Controle variabelen & Ja & Ja & Ja & Ja & Ja & Ja \\
\hline (Pseudo) R-Squared & 0,010 & 0,296 & 0,033 & 0,029 & 0,037 & 0,034 \\
\hline N & 1382 & 902 & 1271 & 1271 & 1104 & 2593 \\
\hline
\end{tabular}

Bron: ROA Transparante arbeidsmarkt 2016. * $p<0.10 * * p<0.05 * * * p<0.01$.

Kolommen (1), (3), (4) en (6) geven de marginale effecten na probit analyse weer.

Kolommen (2) en (5) geven OLS coëfficiënten weer.

Standaardfouten tussen haakjes.

Controle variabelen: geslacht, leeftijd (lineair en kwadraat).

40 Wanneer niet gecontroleerd wordt voor het feit dat men heeft gekozen vanuit het perspectief van wat men leuk vindt, blijken mbo'ers die gekozen vanuit waar zij goed in zijn minder vaak buiten de eigen richting te werken, minder spijt te hebben van de gekozen richting en vaker tevreden met hun baan of functie. 



\section{6 \\ AFWEGINGEN IN HET STUDIEKEUZEPROCES}

\section{Opzet: keuze-experiment}

Het is lastig om met retrospectieve vragen, zoals geschetst in hoofdstuk 5, de afruil die jongeren maken tussen interesses, capaciteiten en arbeidsmarktperspectieven goed te meten. Om die reden bevatte het mbo-supplement een keuze-experiment (vignet) waarin jongeren gevraagd zijn een keuze te maken tussen twee verschillende mboopleidingen die van elkaar verschillen op een zestal relevante attributen m.b.t. arbeidsmarktkenmerken van de opleidingen, schoolkenmerken en de mate waarin de opleiding passend is. ${ }^{41}$ De attributen en de gerandomiseerde waarde ervan zijn als volgt:

\section{Arbeidsmarktkenmerken:}

- kans op werk na afstuderen: slecht / gemiddeld / goed

- doorgroeimogelijkheden: slecht / gemiddeld / goed

Schoolkenmerken

- reistijd naar school: minder dan 15 minuten / 30 minuten / 60 minuten/ meer dan 60 minuten

- kwaliteit van stagebegeleiding: slecht/gemiddeld/goed

Passende opleiding:

- Studie passend bij capaciteiten: slecht / gemiddeld / goed

- Studie passend bij interesses: slecht / gemiddeld/goed

41 Voor een verantwoording van vignetstudies, zie Louviere J.J., Hensher D.A. \& Swait J.D. (2000), Stated choice methods: Analysis and applications, Cambridge University Press. Het gebruik van vignetstudies in de economische wetenschap is wijdverpreid (zie bijvoorbeeld Barsky R.B., Juster F.T., Kimball M.S. \& Shapiro M.D. (1997). Preference parameters and behavioral heterogeneity: An experimental approach in the health and retirement study, Quarterly Journal of Economics, Vol. 112, 537-579. Van Soest A. \& Vonkova, H. (2014). How sensitive are retirement decisions to financial incentives? A stated preference analysis. Journal of Applied Econometrics, 29(2), 246-264. Over de externe validiteit van vignetstudies, zie bijvoorbeeld Telser, H. \& P. Zweifel, (2007), Validity of Discrete-Choice Experiments Evidence for Health Risk Reduction, Applied Economics, Vol 39. 69-78. 
Omdat de respondenten aan de mbo-monitor zelf hun studiekeuze al achter de rug hebben, was het niet vanzelfsprekend om ze te vragen om de keuze voor zichzelf te maken. Wij plaatsen de mbo-gediplomeerden in de rol van 'adviseur' en vragen ze een vmbo'er te adviseren welke opleiding te gaan volgen, waarbij jongens is gevraagd om een jongen te adviseren, en meisjes om een meisje te adviseren. Om het realistisch te houden is hierbij gekozen voor veel voorkomende namen in het geboortecohort van de mbo-gediplomeerden (Thomas en Laura). Respondenten zijn vijf keer gevraagd om een afweging te maken tussen twee opleidingen, waarbij de volgorde van de relevante attributen tussen respondenten gerandomiseerd is. Een voorbeeld van een dergelijk vignet is opgenomen in figuur $4 . .^{42}$

\section{FIGUUR 4 Voorbeeld van een vignet}

Q9.1. We willen je voorstellen aan Thomas, hij zit in zijn laatste jaar van het vmbo. Daarna wil hij een vervolgopleiding gaan volgen in het mbo.

In de volgende vijf vragen leggen we steeds twee mbo-opleidingen naast elkaar. De mbo-opleidingen verschillen op een zestal kenmerken van elkaar: de mate waarin de studie passend is bij zijn capaciteiten en interesses, kans op werk na afstuderen, de doorgroeimogelijkheden, de reistijd naar school en de kwaliteit van stagebegeleiding. Andere niet genoemde kenmerken zijn hetzelfde voor de beide mbo-opleidingen.

Q9.2. Keuze 1 van 5:

Welke van de twee mbo-opleidingen zou jij Thomas adviseren?

\begin{tabular}{|lll|}
\hline Kenmerkend mbo-opleiding & mbo-opleiding A & mbo-opleiding B \\
\hline Passend bij capaciteiten & goed & slecht \\
\hline Passend bij interesses & gemiddeld & goed \\
\hline Kans op werk na afstuderen & hoog & hoog \\
\hline Doorgroeimogelijkheden & goed & goed \\
\hline Reistijd naar school (enkele reis) & meer dan 60 minuten & 30 minuten \\
\hline Kwaliteit van stagebegeleiding & slecht & slecht \\
\hline A B & & \\
\hline O & & \\
\hline
\end{tabular}

\section{Resultaten van de vignetstudie}

Als wij de gekozen opleiding relateren aan de kenmerken van die opleiding (figuur 5), ${ }^{43}$ kunnen wij een aantal conclusies trekken. Ten eerste, alle in het vignet genoemde kenmerken blijken relevant voor de keuze. Ten tweede, de mate waarin de opleiding passend is bij de interesses heeft het grootste effect op het wel/niet kiezen van de oplei-

42 In het vignet zijn de uitkomsten gegeven. In de praktijk weet men echter niet altijd hoe de match met interesses precies zal zijn en wat de arbeidsmarktperspectieven feitelijk zullen zijn. Over de rol van onzekerheid in de studie- en beroepskeuze, zie: Fouarge, D., Kriechel, B., \& Dohmen, T. (2014), Occupational sorting of school graduates: The role of economic preferences, Journal of Economic Behavior \& Organization, 106, 335-351.

43 De figuur geeft de marginale effecten weer van een probit model voor opleidingskeuze (1 indien gekozen), met de kenmerken van de opleidingen als regressoren. 
ding. Ten derde, in deze setting, waarin de arbeidsmarktperspectieven voor opleidingen expliciet benoemd worden blijken jongeren sterk te reageren op deze informatie in hun keuze. Het effect van arbeidsmarktkenmerken is in omvang vergelijkbaar met dat van passendheid bij de capaciteiten. Ten slotte, het signaal 'slecht' (of het nu gaat om slecht passend bij interesses, of slechte arbeidsmarktkansen) heeft een groter negatief effect op het kiezen voor een opleiding dan de tegenovergestelde boodschap 'goed' heeft op de kans dat de opleiding wél gekozen wordt. Men moet hier wel voorzichtig blijven bij deze interpretatie omdat het niet duidelijk is of respondenten de signalen slecht, gemiddeld en goed inderdaad zien als onderdeel van een continuüm, maar de bevinding is in lijn met onderzoek van Pistolesi (2017) ${ }^{44}$ waar uit blijkt dat studenten gevoeliger zijn voor negatieve feedback bij hun keuze voor een major. Het is eveneens consistent met de literatuur rond risicoaversie. ${ }^{45}$

\section{FIGUUR 5 Verschil in kans dat opleiding gekozen wordt, naar kenmerken van opleiding}

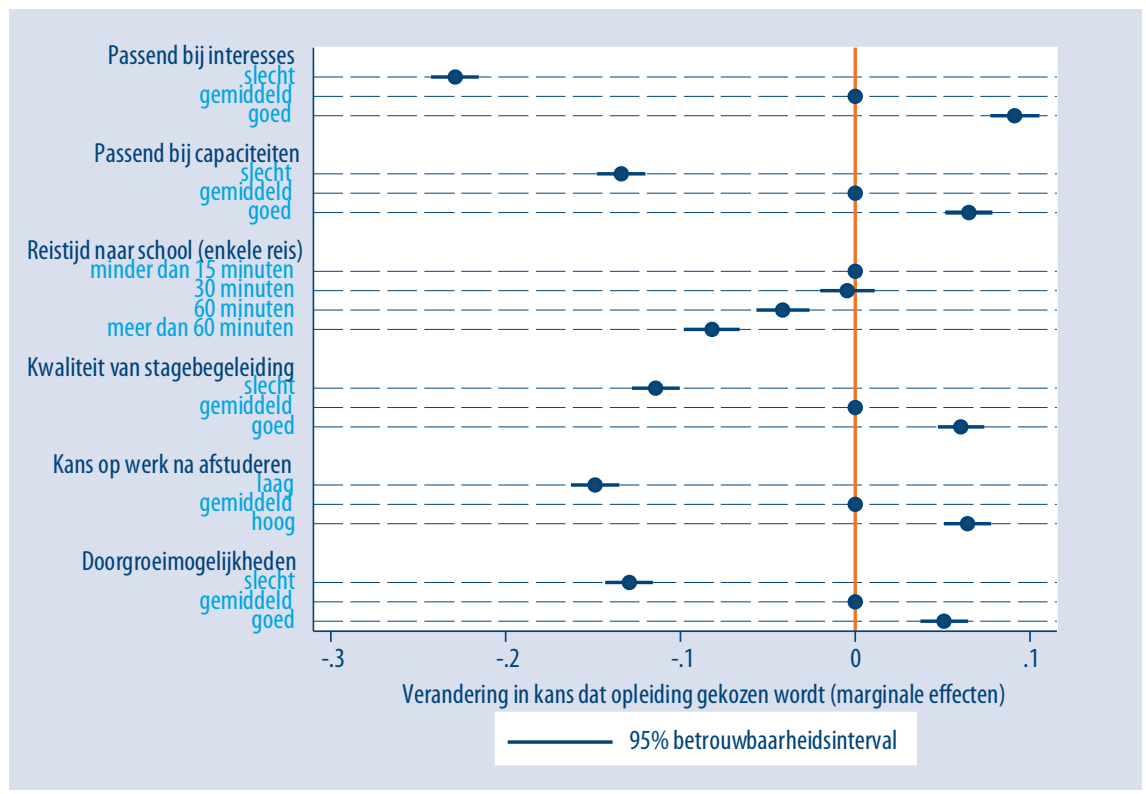

Bron: ROA, Transparante arbeidsmarkt 2016

\section{Afruil interesses en arbeidsmarktkansen}

Dergelijke data maken het mogelijk om de afruil die jongeren maken tussen verschillende kenmerken van opleidingen te kwantificeren. Figuur 6 laat zo een afruil zien

44 Pistolesi, N. (2017). Advising students on their field of study: Evidence from a French university reform, Labour Economics, 44, 106-121.

45 Kahneman, D., \& Tversky, A. (1979). Prospect theory: An analysis of decision under risk, Econometrica, 47(2), 263-291. 
tussen de mate waarin de opleiding passend is bij de interesses (op de horizontale as) en de kans op werk na diplomering (de lijnen in de figuur). Voor de figuur is er voor gekozen om de verschillen in kansen te laten zien ten opzichte van de 'slechtste' optie: een opleiding met een slechte match met interesses en ook nog eens een slechte kans op werk na het behalen van het diploma. ${ }^{46}$ De figuur laat twee belangrijke zaken zien. Ten eerste, gegeven de match met interesses, stijgt de kans dat de opleiding gekozen wordt met het beter worden van de kans op werk bij diplomering. Bij een opleiding met een goede match is de kans 16\%-punten hoger dat deze wordt verkozen wanneer de kansen op werk gemiddeld zijn vergeleken met slecht (verschil tussen punten $A$ en B) en zelfs 22\%-punten hoger bij goede perspectieven (verschil tussen punten A en C). Al deze verschillen zijn significant. Ten tweede laat de figuur zien dat de kans dat een opleiding gekozen wordt met een gemiddelde match met interesses, en goede of zelfs gemiddelde perspectieven op werk, significant hoger is dan een opleiding die weliswaar een goede match biedt met interesses, maar slechte of zelfs gemiddelde perspectieven op werk heeft (punten D en E zijn significant hoger gelegen dan punt A). Dit suggereert dat jongeren mogelijk zouden switchen van opleidingskeuze -van de opleiding met de beste match met interesses naar de opleiding met de een na beste match- wanneer zij informatie krijgen over de verschillen in arbeidsmarktperspectieven van opleidingen.

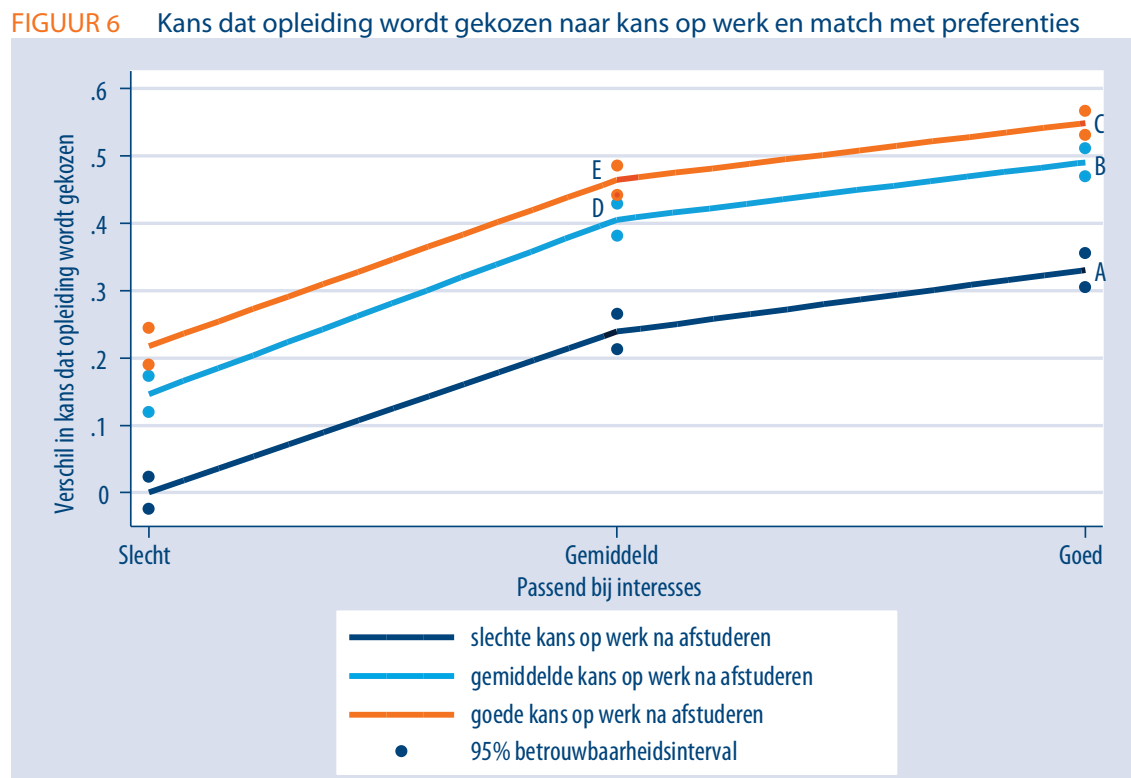

Bron: ROA, Transparante arbeidsmarkt 2016 zien voor de kans dat een opleiding wordt gekozen, waarbij de match met interesses en kans op werk na afstuderen zijn geïnteracteerd en de overige kenmerken op gemiddeld staan (de reistijd op 30 minuten). 
Een vergelijkbare afruil kunnen wij laten zien met de doorgroeimogelijkheden. Figuur 7 laat het verschil zien in kans dat de opleiding wordt gekozen naar de passendheid van de opleiding bij interesses en de doorgroeimogelijkheden op de arbeidsmarkt. Het laat een vergelijkbaar patroon zien aan dat van figuur 6 . Echter, bij een opleiding die slecht past bij de interesses is het verschil in kans dat de opleiding gekozen wordt niet significant verschillend bij gemiddelde en goede doorgroeimogelijkheden. De afruil tussen interesses en doorgroeimogelijkheden wordt daarentegen wel gevonden.

FIGUUR 7 Kans dat opleiding wordt gekozen naar doorgroei mogelijkheden en match met preferenties

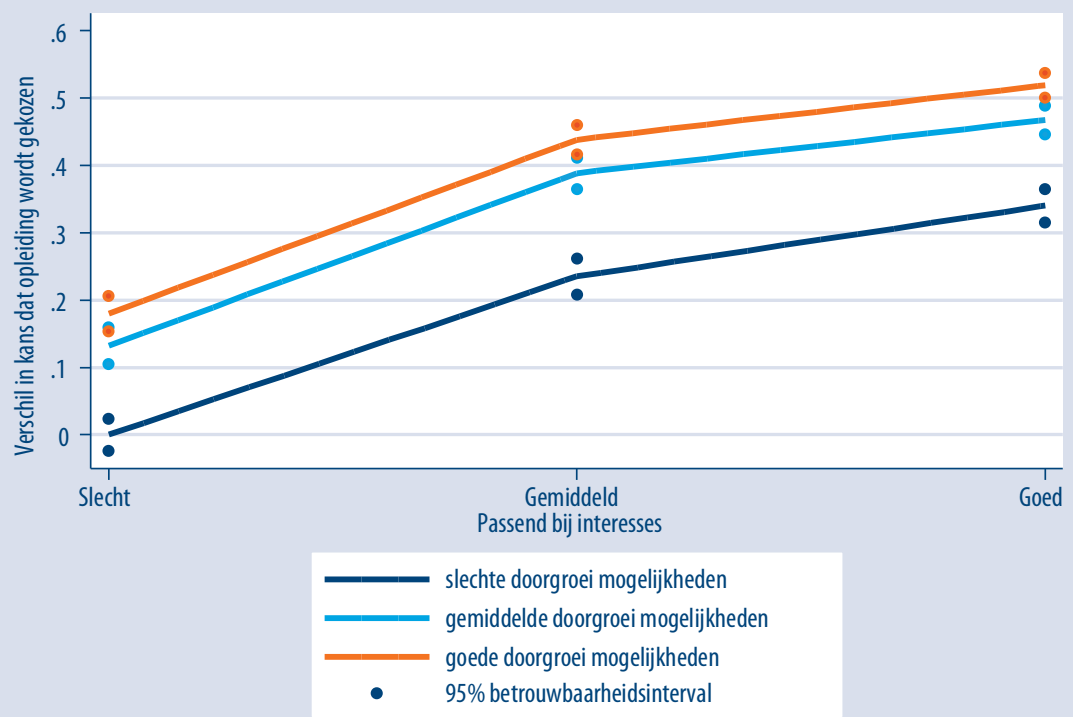

Bron: ROA, Transparante arbeidsmarkt 2016 



\section{7 \\ CONCLUSIE EN DISCUSSIE}

Het essentiële belang van de studiekeuze wordt breed onderkend. In dit rapport onderzoeken we, ten eerste, in welke mate studiekiezers gebruik maken van arbeidsmarktinformatie bij het maken van hun studiekeuzes. Ten tweede, gaan wij in op de afruil tussen preferenties (wat wil ik?), competenties (wat kan ik?) en arbeidsmarktperspectieven (wat kan ik ermee?) in het studiekeuzeproces.

Het studiekeuzeproces is complex en verwachtingen, ervaringen en externe factoren (vrienden, ouders) spelen daar een belangrijke rol bij. ${ }^{47}$ Het studiekeuzeproces is dan ook niet altijd het resultaat van een rationele overweging die jongeren maken ten aanzien van wat zij met hun opleiding kunnen bereiken. Toch blijkt uit wetenschappelijke literatuur dat jongeren wel degelijk reageren op arbeidsmarktinformatie, en dat deze informatie de studiekeuze beïnvloedt. Dit speelt vooral voor jongeren uit laag sociaal economische milieus, wellicht omdat bij hen de informatieachterstand groter is. Literatuur laat tevens zien dat het goed informeren van ouders ook van belang is voor de opleidingskeuzes die hun kinderen maken. Deze literatuur is echter nog schaars en de exacte grootte van het effect van arbeidsmarktinformatie op de studiekeuze verschilt tussen verschillende onderzoeken.

Het kwantitatief onderzoek dat wij hier presenteren is uitgevoerd met behulp van een in 2016 gehouden supplement van de BVE-monitor van ROA. Ten eerste bekijken we welke informatiebronnen (of activiteiten) het meest intensief gebruikt worden door mbo'ers, en wat voor soort informatie ze uit deze bronnen en activiteiten halen. Daarna onderzoeken we de overwegingen die mbo-gediplomeerden zelf hebben gemaakt in hun studiekeuze, en relateren we deze overwegingen aan arbeidsmarktuitkomsten vroeg in hun loopbaan. We vinden dat de studiekeuzefactoren:'preferenties' en 'carrièremogelijkheden' statistische significante verbanden hebben met verschillende, arbeidsmarktuitkomsten. In het bijzonder laten onze analyses zien dat gegeven de mate waarin preferenties en eigen capaciteiten een rol hebben gespeeld in de eigen opleidingskeuze, jongeren die hun carrièreperspectieven (heel) sterk hebben laten meewegen een gunstigere arbeidsmarktsituatie hebben: ze hebben vaker werk, verdienen een hoger uurloon, hebben vaker werk op niveau en een betere aansluiting met de studierichting,

47 Daarbij komt nog dat cognitieve processen wellicht minder belangrijks zijn dan affectieve processen (Zajonc, R. B. (1980), Feeling and thinking: Preferences need no inferences. American psychologist, 35(2), 151-175). 
zijn meer tevreden met hun functie/beroep en hebben minder vaak spijt van hun opleidingskeuze.

Het is lastig om de afruil die studenten maken tussen deze overwegingen te meten met dit soort retrospectieve vragen. Daarom hebben we ook, als onderdeel van ons onderzoek, een keuze-experiment uitgevoerd (vignetstudie). Hierin wordt de afruil tussen preferenties, competenties en arbeidsmarktperspectieven gekwantificeerd. Door de voorgenomen keuze van studiekiezers te analyseren, kunnen we onze kennis over hun studiekeuzeproces verbeteren. Onze analyses suggereren ten eerste dat het signaal 'slecht' (of het nu gaat op slecht passend bij interesses, of slechte arbeidsmarktkansen) een groter effect heeft op het niet kiezen voor een opleiding dan de tegenovergestelde boodschap 'goed' op de kans dat de opleiding wél gekozen wordt. Ten tweede suggereren onze analyses dat studiekiezers bereid zouden zijn om te switchen van de opleiding van hun eerste voorkeur naar hun tweede voorkeur als de arbeidsmarktperspectieven voor de opleiding van hun tweede keuze beter zijn en als dit ze expliciet wordt verteld. Dit suggereert dat jongeren, afgezien van de standaard loopbaanoriëntatie en -begeleiding (LOB) activiteiten die zij ondernemen, baat hebben bij transparante arbeidsmarktinformatie. 


\section{BIJLAGE: \\ INFORMATIEKANALEN, HUN WAARDE EN STUDIEKEUZEFACTOREN}

Gebruikte informatiekanalen bij opleidingskeuze

FIGUUR B1.1 Gebruikte informatiekanalen bij opleidingskeuze, naar mbo-richting

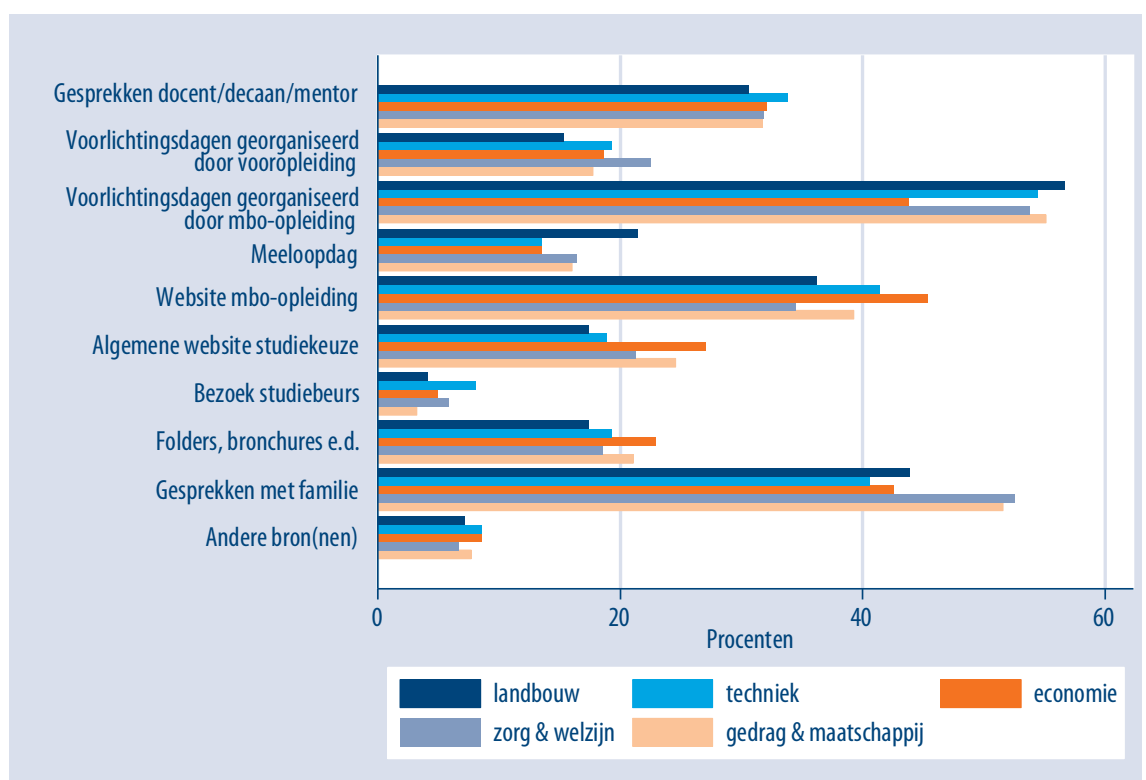

Bron: ROA, Transparante arbeidsmarkt 2016 
FIGUUR B1.2 Gebruikte informatiekanalen bij opleidingskeuze, naar mbo-niveau

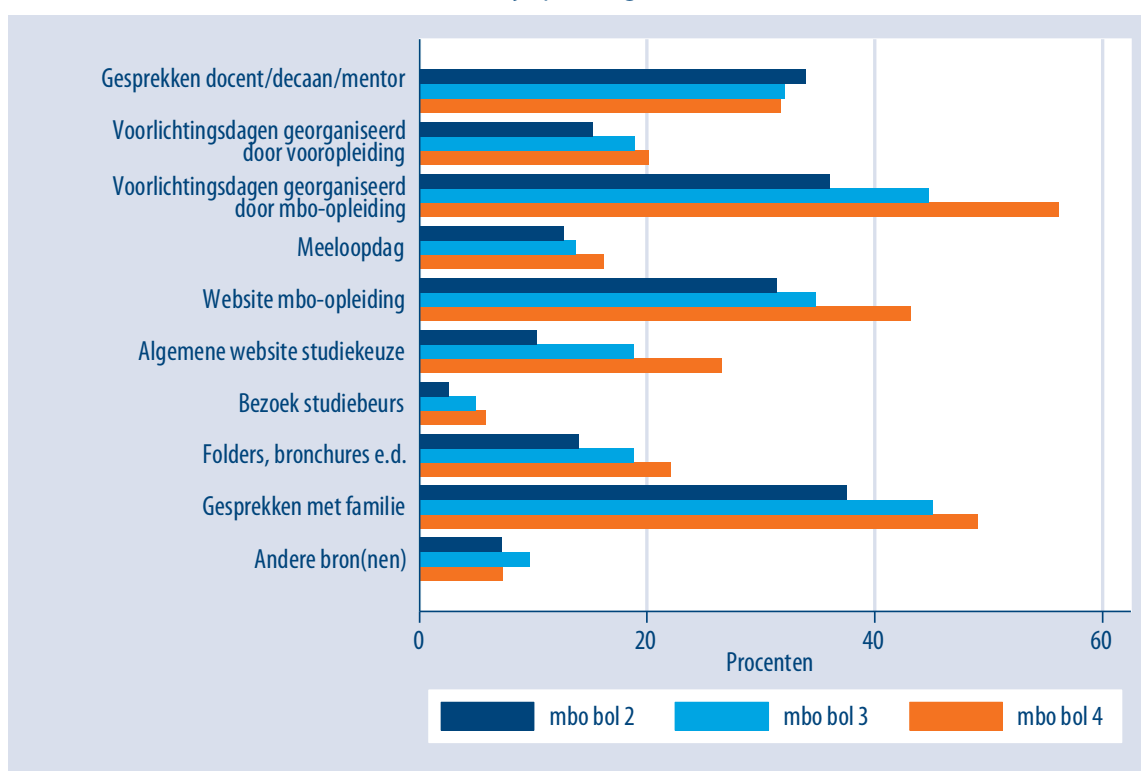

Bron: ROA, Transparante arbeidsmarkt 2016

\section{Waarde van informatiekanalen bij opleidingskeuze}

FIGUUR B2.1 Waarde van gesprek met docent/decaan/mentor bij opleidingskeuze, naar mborichting

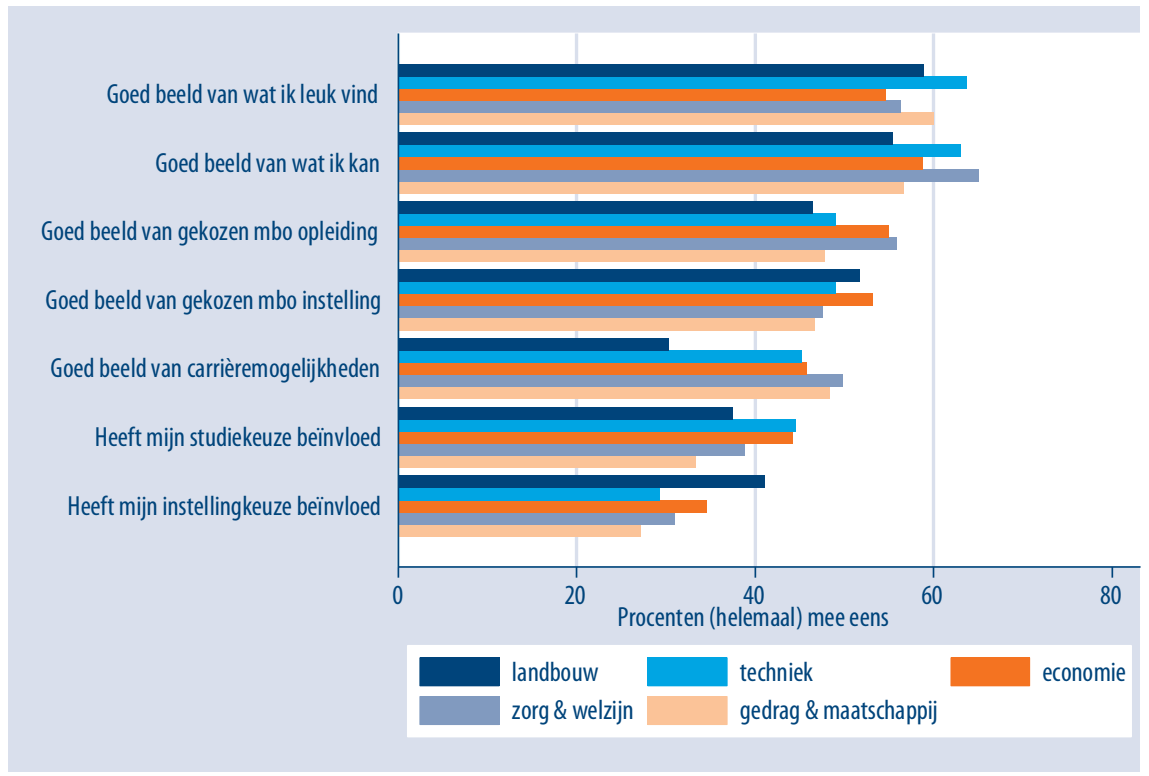

Bron: ROA, Transparante arbeidsmarkt 2016 
FIGUUR B2.2 Waarde van gesprek met docent/decaan/mentor bij opleidingskeuze, naar mboniveau

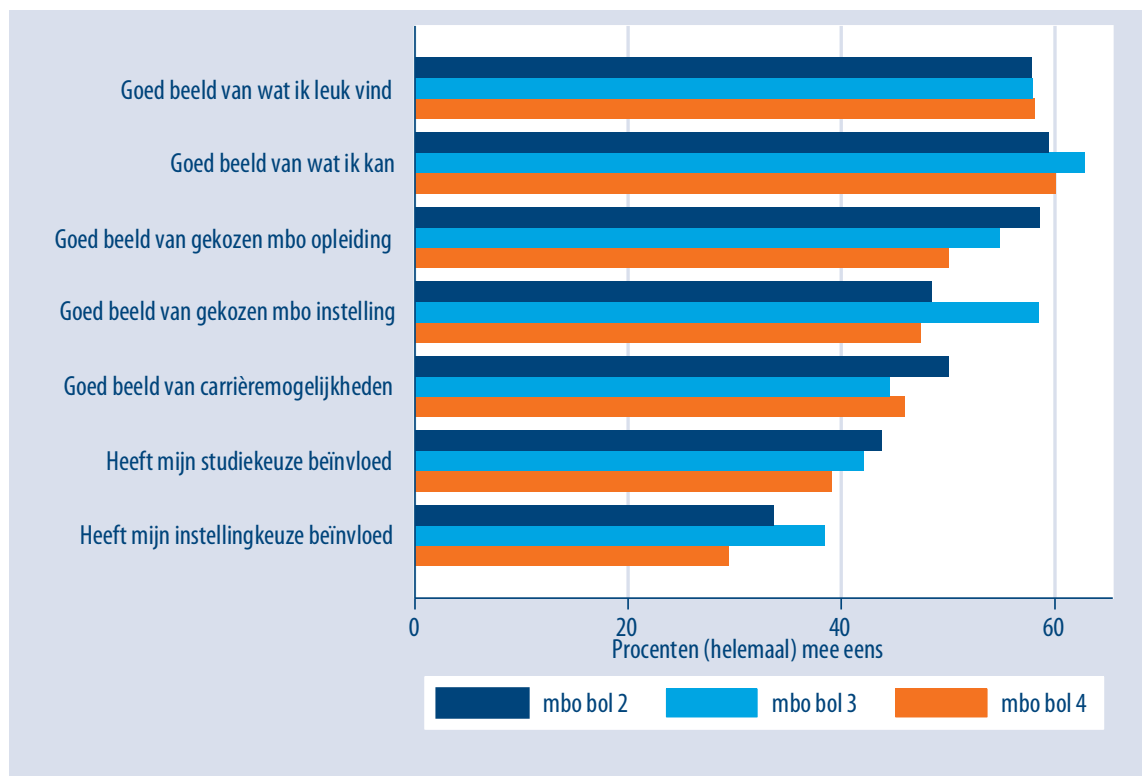

Bron: ROA, Transparante arbeidsmarkt 2016

FIGUUR B2.3 Waarde van bezoek aan voorlichtingsdag bij opleidingskeuze, naar mbo-richting

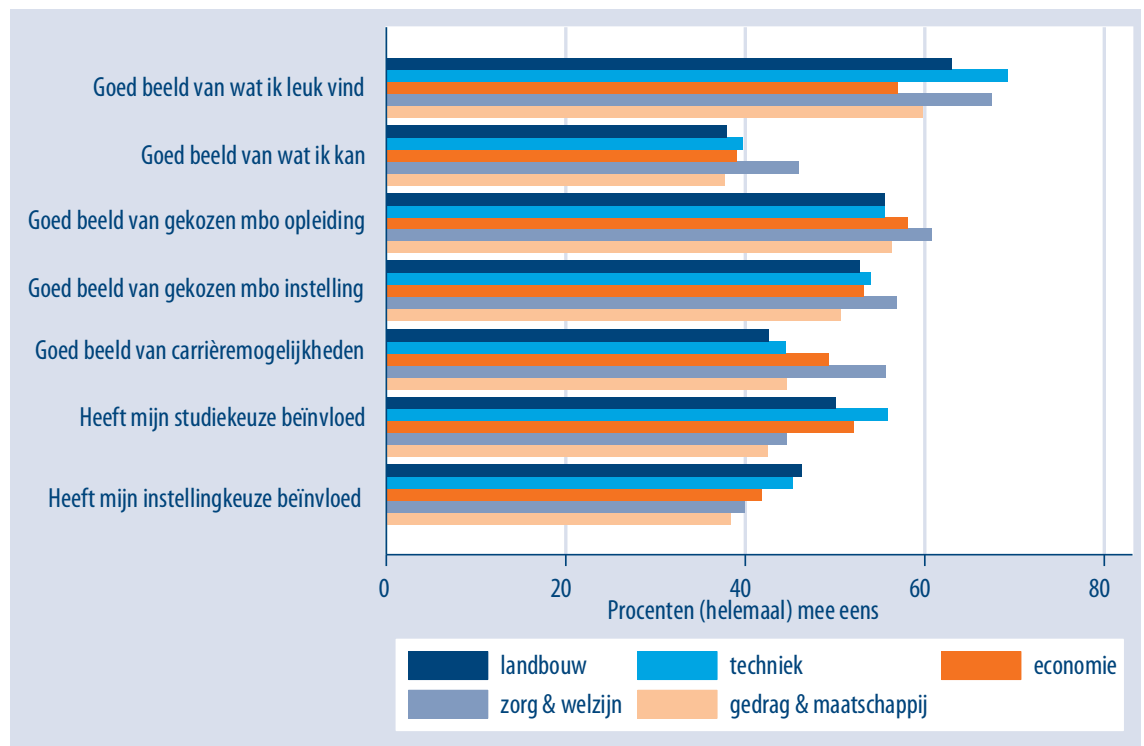

Bron: ROA, Transparante arbeidsmarkt 2016 
FIGUUR B2.4 Waarde van bezoek aan voorlichtingsdag bij opleidingskeuze, naar mbo-niveau

Goed beeld van wat ik leuk vind

Goed beeld van wat ik kan

Goed beeld van gekozen mbo opleiding

Goed beeld van gekozen mbo instelling

Goed beeld van carrièremogelijkheden

Heeft mijn studiekeuze beïnvloed

Heeft mijn instellingkeuze beïnvloed

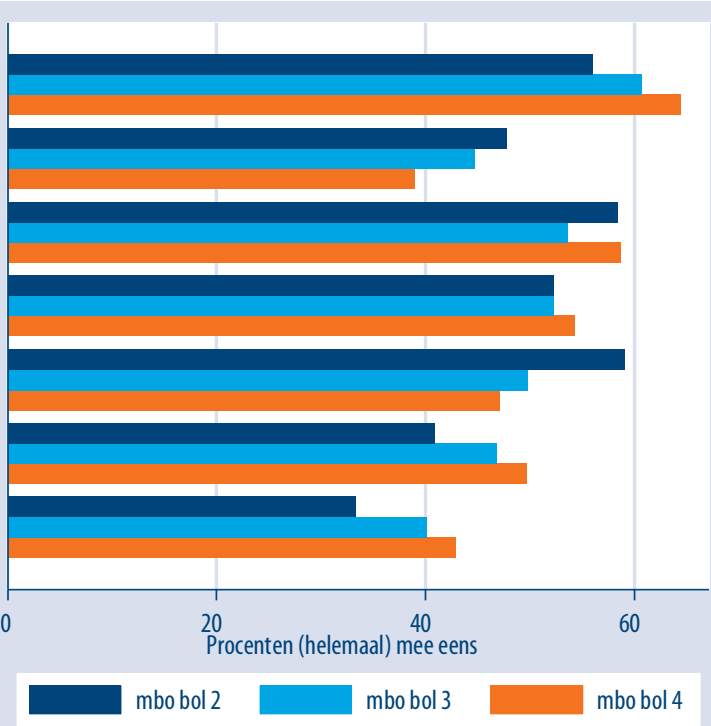

Bron: ROA, Transparante arbeidsmarkt 2016

FIGUUR B2.5 Waarde van gesprek met familie/vrienden bij opleidingskeuze, naar mbo-richting

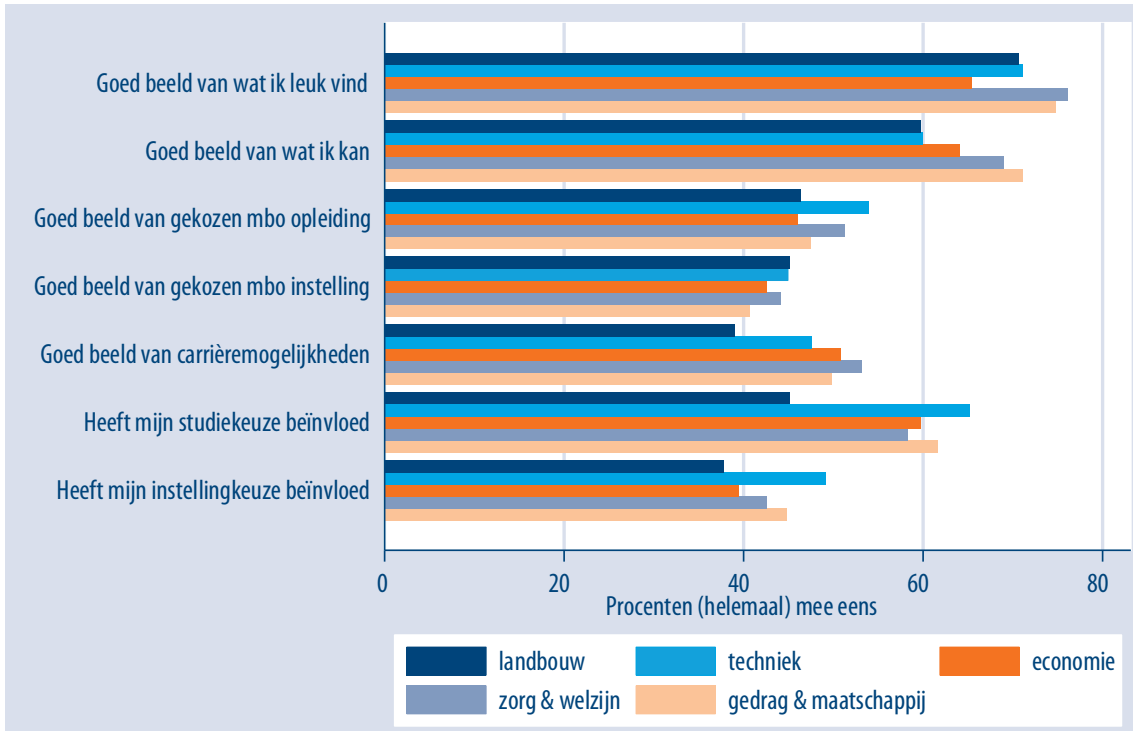

Bron: ROA, Transparante arbeidsmarkt 2016 
FIGUUR B2.6 Waarde van gesprek met familie/vrienden bij opleidingskeuze, naar mbo-niveau

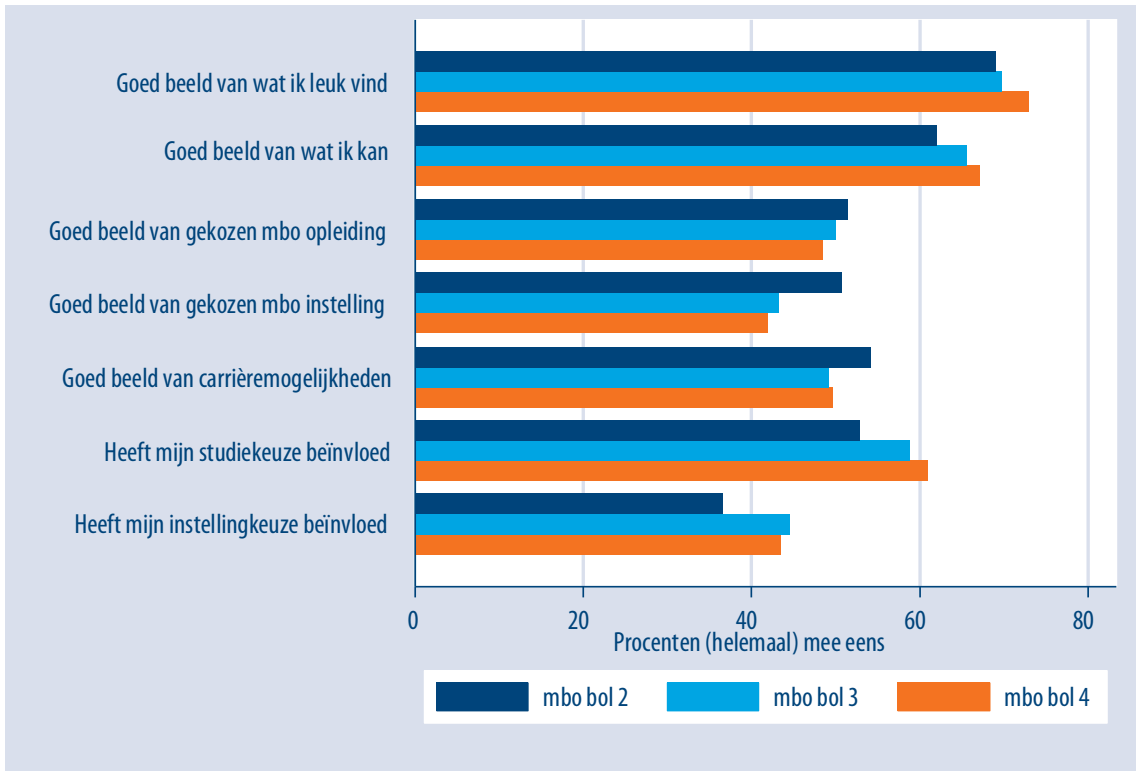

Bron: ROA, Transparante arbeidsmarkt 2016

\section{Studiekeuzefactoren}

FIGUUR B3.1 Aspecten die meegewogen zijn in de opleidingskeuze, naar mbo-richting

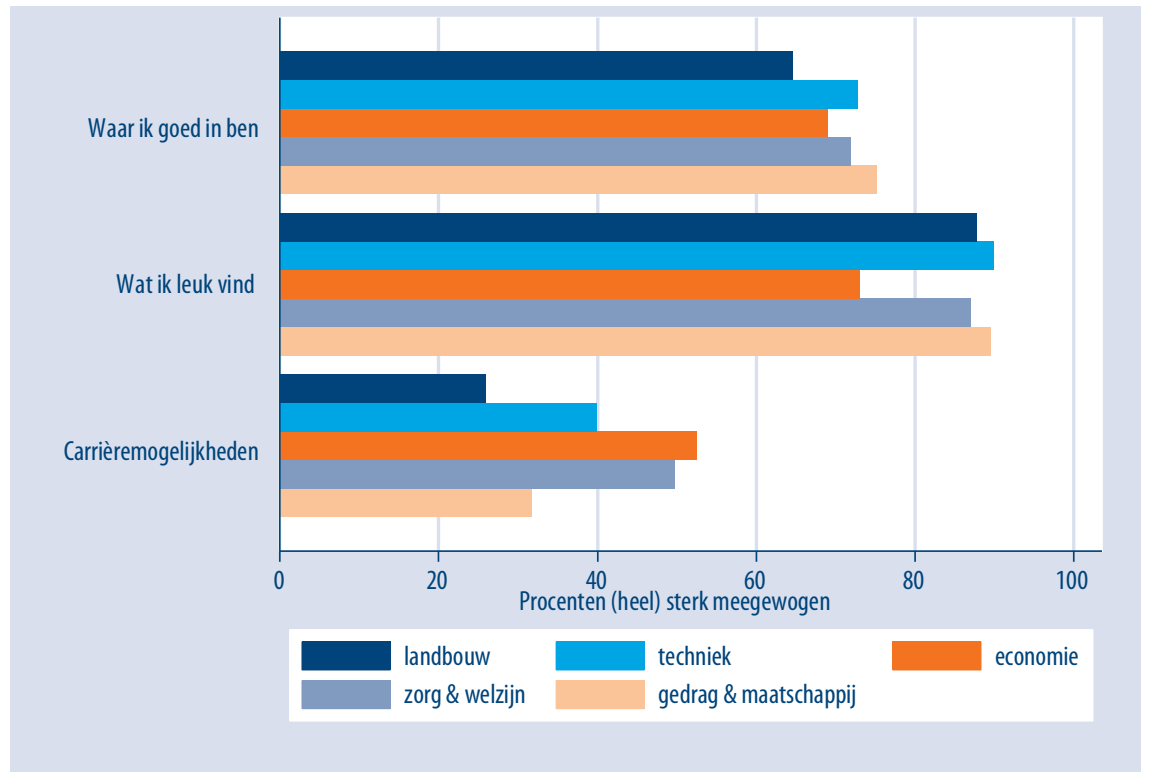

Bron: ROA, Transparante arbeidsmarkt 2016 
FIGUUR B3.2 Aspecten die meegewogen zijn in de opleidingskeuze, naar mbo-niveau

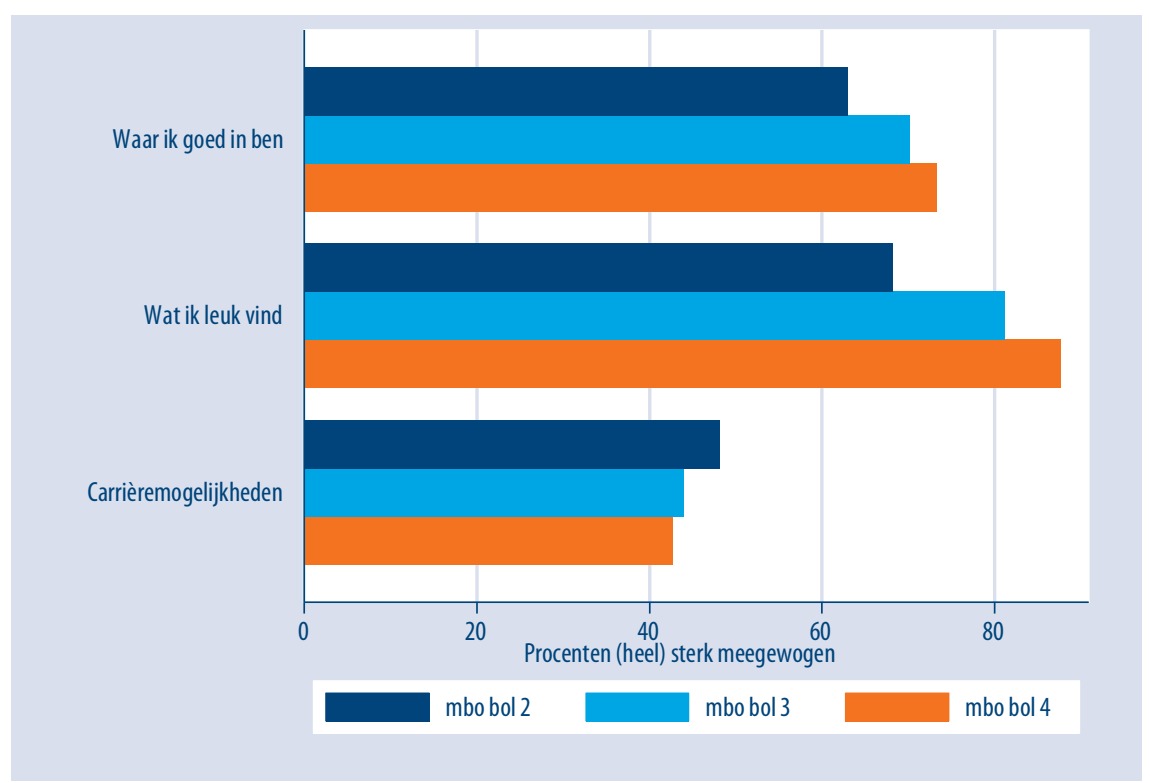

Bron: ROA, Transparante arbeidsmarkt 2016 